\title{
Cervical spine surgery in the ancient and medieval worlds
}

\author{
James Tait Goodrich, M.D., Ph.D. \\ Leo Davidoff Department of Neurological Surgery, Albert Einstein College of Medicine, \\ Children's Hospital of Montefiore, Bronx, New York
}

\begin{abstract}
$\checkmark$ The early historical literature on cervical spine surgery lacks printed material for review, and we can rely only on pathological material from the prehistoric period that has survived as a result of anthropological investigations. After the introduction of Egyptian and early Hellenic medicine, some written material became available. This paper reviews these materials, from both books and manuscripts, in an effort to understand the development of cervical spine surgery from the perspectives of the personalities involved and the early surgical practices used. The review thus considers the following five eras of medicine: 1) prehistoric; 2) Egyptian and Babylonian; 3) Greek and early Byzantine; 4) Middle Eastern; and 5) medieval. (DOI: 10.3171/FOC-07/07/E7)
\end{abstract}

KEY WORDS - cervical spine surgery - history of neurosurgery

$\mathrm{F}$ OR AN EARLIER PAPER in Neurosurgical Focus, ${ }^{25}$ I composed a historical vignette on the history of spine surgery in the ancient and medieval periods. In this paper I have provided a more focused look at surgery of the cervical spine. To provide this perspective the general material on the spine from the original paper was removed and I have added a more in depth look at cervical spine surgery. I was able to incorporate some more relevant material into this paper on cervical spine surgery by researching primary source material. I have also added additional illustrations as they pertain to this subject.

One could call this effort a palimpsestic effort at spine surgery by bringing forth new material as it becomes available, but I have found that literature involving the early periods in the development of cervical spine surgery is sparse. Fires, internecine wars, conquests, and other changes have left little written material intact that originated in the ancient world. Fragments of manuscripts and more commonly copies of early works, some quite inaccurate, are all that the modern scholar can examine. Furthermore, ancient medicine lacked essential concepts such as an understanding of anatomy, recognizing disease, and comprehending the origin of illness in an organic system. The failure to grasp these vital principles slowed or even prevented the evolution of the practice of medicine. Cervical spine surgery, and neurosurgery itself, is truly a develop-

Abbreviation used in this paper: $\mathrm{CSF}=$ cerebrospinal fluid. ment of very recent origin, at least so far as the documentary record is concerned. Despite these limitations, a review of some of the existing materials concerning the development of cervical spine surgery in the prehistoric, ancient, and medieval worlds can strengthen our understanding.

\section{Prehistoric Period}

The trephine and the art of trephination are well known to neurosurgeons. People in many cultures have used this primitive surgical technique, and in most cases the reasons for doing so remain elusive, other than its use for head trauma. In certain areas of Peru, graveyards (some dating back to $400 \mathrm{BC}$ ) have been found in which the number of trephined skulls far exceeds what would be considered a likely number of head injuries. This finding has led modern scholars to question the reasons for this practice, leading to theories such as headaches, psychological illness, head injury, and the release of spirits or demons, among other possibilities. In many instances the clearly healed head wounds demonstrated that many such trephinations were premortem rather than postmortem procedures, with good outcomes.

Over the years a number of skeletons dating back to this period have been exhumed during anthropological investigations and a number of cervical spine disorders have been revealed. ${ }^{52,54}$ Disorders such as osteomyelitis, osteochondroma, arthritis, cervical fractures, bone tumors, and 


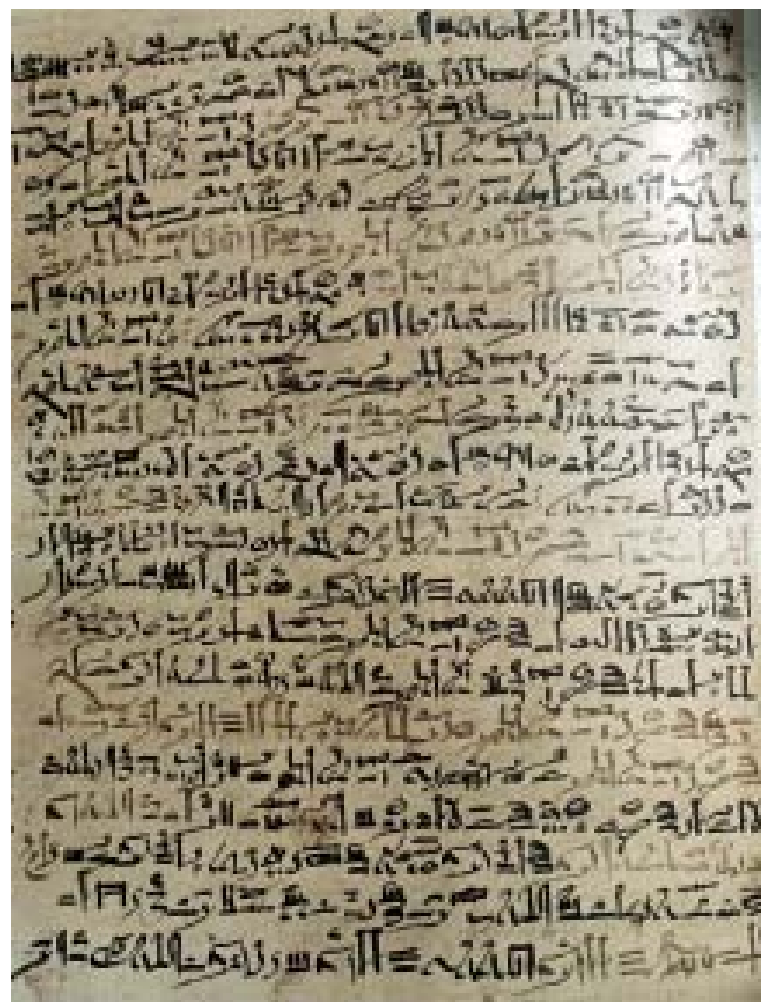

FIG. 1. A leaf from the original Edwin Smith papyrus in which Case 31 is discussed (cervical fracture). Reprinted from J. H. Breasted: The Edwin Smith Surgical Papyrus. Chicago: University of Chicago Press, 1930.

osteitis have all been well described. Probably the most common pathological lesion seen in the spine is tuberculosis, or Pott disease of the spine. ${ }^{57}$ Only a few of the cases that are well documented suggest any sort of surgical intervention for cervical spine trauma or disease.

\section{Ancient Period}

For the ancient physician, the fear of operating on any part of the body was a real one, especially when one had to deal with the cervical spine. Two centuries before the birth of Christ, King Hammurabi of Babylon (1955-1912 BC) introduced a set of equitable laws that dealt with matters of everyday life such as marriage, slavery, land purchase, and, of course, medicine. Compared to Hammurabi's Code, modern issues of medical malpractice seem a bit tame. The penalties established in this codex for making surgical errors led surgeons of those times to approach patients with some trepidation. In Hammurabi's Code, nine paragraphs are devoted to the physician, and one in particular deals with the operator who carries a bronze knife (scalpel) for wound care:

If a physician makes a wound and cures a freeman, he shall receive ten pieces of silver, but only five if the patient is the son of a plebeian or two if he is a slave.

However it is decreed that if a physician treats a patient

"with a metal knife for a severe wound and has caused the man to die - his hands shall be cut off" (Code of Hammurabi).
The thought of losing one's hands most likely kept many potential surgeons from operating on the cervical spine. In an era that long preceded antisepsis, anesthesia, and good neurological localization, the ability to operate on a region as complex as the cervical spine must have been very remote.

\section{Egyptian and Babylonian Medicine: The Embryonic Period}

Early written material that remains extant goes back only to the Egyptian period, an era that covers approximately 30 successive dynasties. The Egyptians claim to have produced the earliest known practicing physician, Imhotep (3000 BC). The embalming practices of the Egyptians suggest that they knew a good deal about internal anatomy, but how such knowledge affected their practice of medicine or surgery remains poorly understood. The first concept of the spine is introduced in the written literature by the hieroglyphic letter "djed," which symbolized the spinal column ${ }^{47}$ Fortunately for the modern scholar interested in studying very early medical and surgical material from this epoch, three medically related documents (or papyri) have been preserved. These early manuscripts are now referred to as the Ebers, Hearst, and Edwin Smith papyri, named after the individuals who either owned or discovered them. The history of each document remains fascinating reading in its own right. ${ }^{5,8,17,18}$

Review of this early material makes it clear that ana-

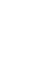

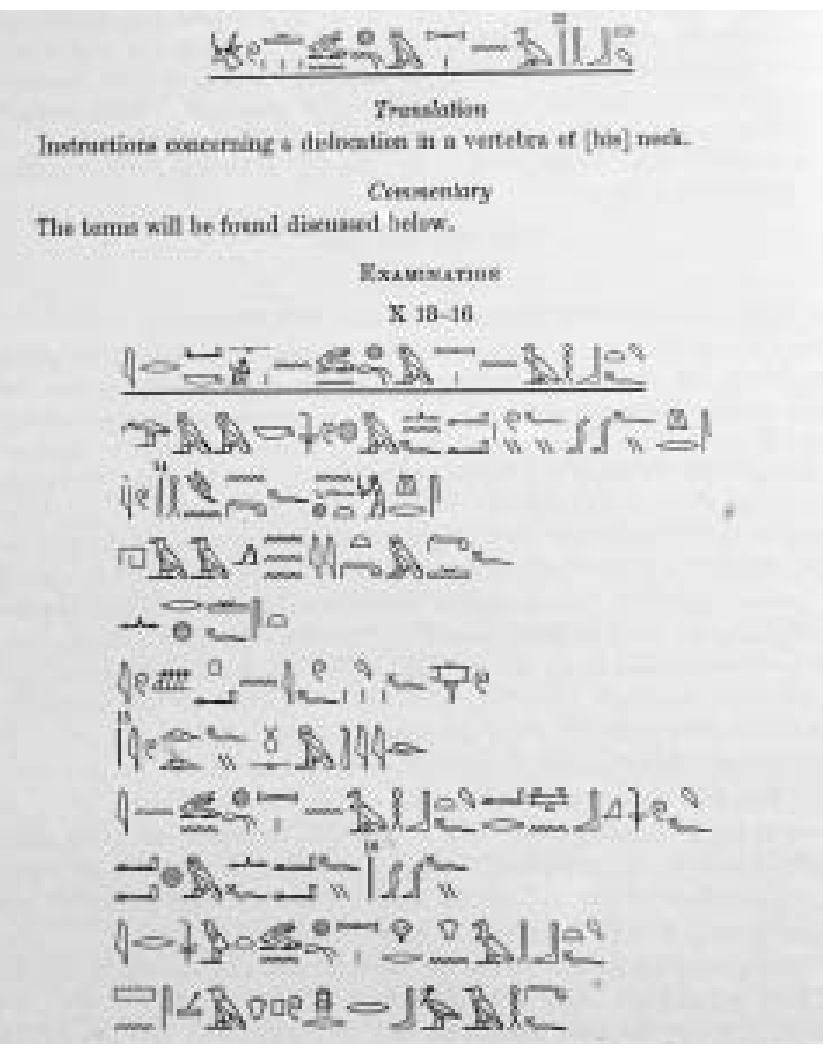

FIG. 2. Leaf showing the Breasted translation of Case 31 (a cervical fracture). Reprinted from J. H. Breasted: The Edwin Smith Surgical Papyrus. Chicago: University of Chicago Press, 1930. 


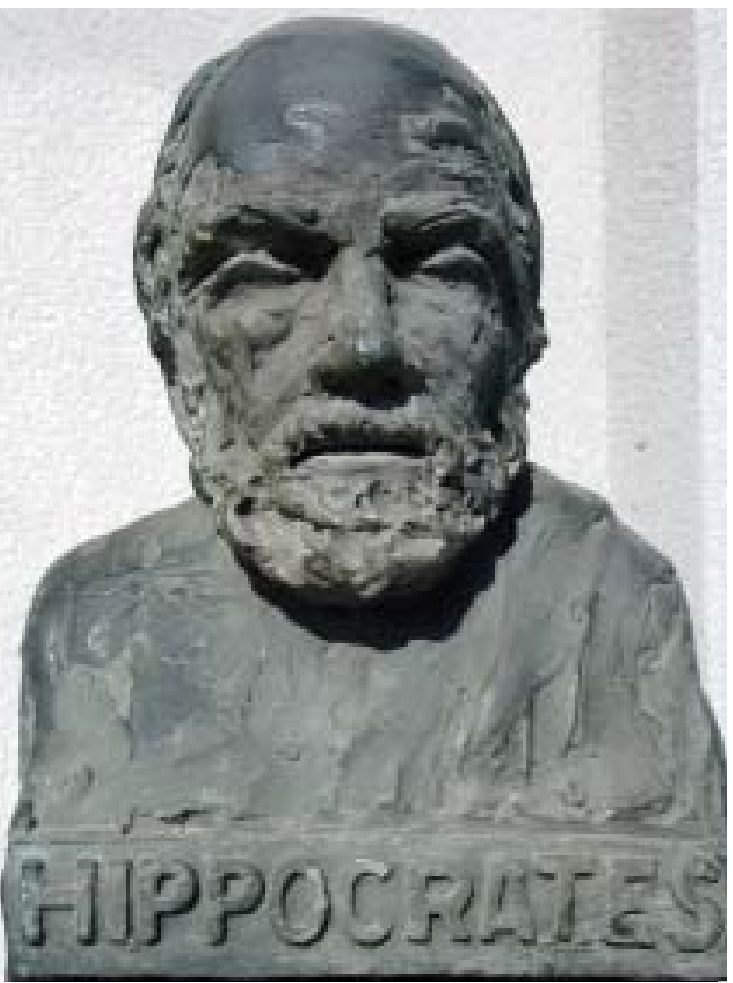

FIG. 3. Photograph of a bust of Hippocrates. From the author's personal collection.

tomical dissection was performed in this period. An examination of the papyri also reveals that the practice of medicine was based largely on magic and superstition. Therapeutic measures depended on simple principles, most of which allowed nature to provide restoration of health with little intervention, a concept more fully developed later by the Asclepiads. One of the most significant advances by this culture was the treatment of injury, because the Egyptians realized that immobilization of broken limbs or the spine was important. For treatment of these disorders they commonly prescribed stabilization using a splint. In addition, the Egyptians and early Babylonians provided a wealth of material that dealt with materia medica, as several surviving pharmacopeias of considerable substance clearly attest.

The early Egyptians contributed enormously to medicine, literature, and mathematics, and fortunately some of the relevant records have survived. The earliest known papyrus that deals with medicine was written approximately five hundred years after Hammurabi; including some 107 pages of hieratic writing, the Ebers papyrus is the oldest medical text believed to exist. ${ }^{5}$ This papyrus is of interest to the modern scholar because of its advocacy of surgical practice. It describes the removal of tumors, and even the surgical drainage of abscesses. A careful review of the text, however, reveals no surgical intervention for cervical trauma or cervical disease (Figs. 1 and 2).

The earliest papyrus to include an extensive discussion of medicine and surgery, and in particular cervical spine disease, is the Edwin Smith papyrus. This papyrus is believed to have been written after $1700 \mathrm{BC}$, during the time

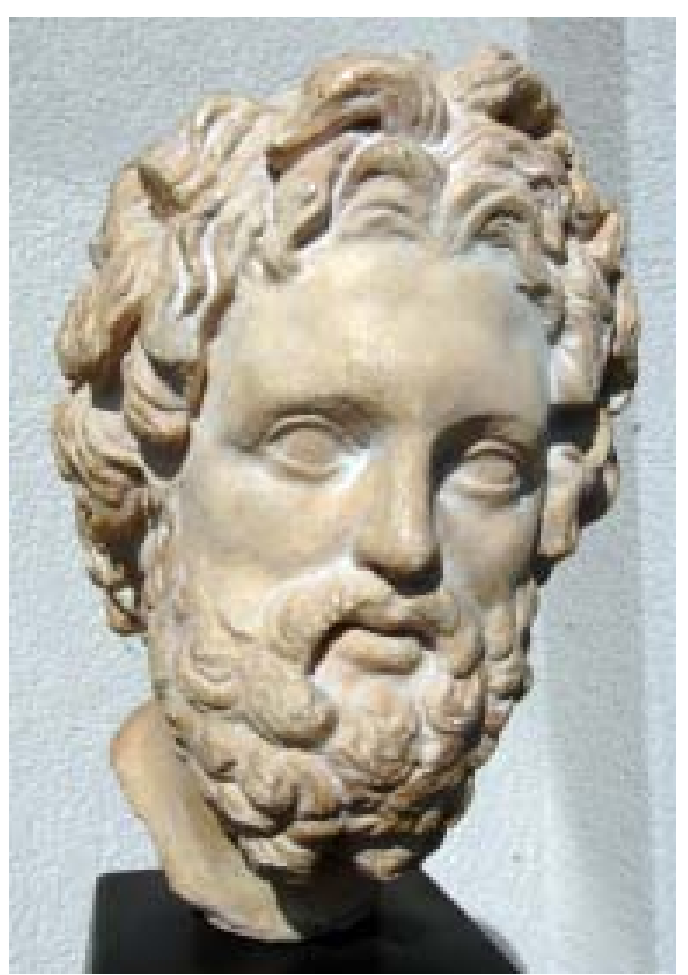

FIG. 4. Photograph of a bust of Aesculapius. From the author's personal collection.

of the New Kingdom. ${ }^{8}$ This papyrus is considered to be the oldest book on surgery per se, and comprises a scroll $15 \mathrm{ft}$ in length and $1 \mathrm{ft}$ in width.

The history involved in the discovery of the Edwin Smith papyrus remains an especially interesting story of bibliomania. Its discovery remains a bit obscured by intrigue and perhaps a bit of malfeasance. Edwin Smith has variously been described as an adventurer, money lender, a dealer and forger of antiquities, pioneer in the study of Egyptian science, and a man of "great intellectual gifts." Smith, while in Luxor, acquired the papyrus under controversial circumstances. Some scholars believe that Smith legitimately purchased the scroll from an Egyptian businessman named Mustafa Agha, but others claim that he bought it illegally from unscrupulous tomb raiders. ${ }^{8,17}$ Regardless of the methods by which he obtained the manuscript, Smith recognized its importance and made efforts towards a first translation. The papyrus remained in Smith's possession until his death in 1906, after which his daughter donated it to the New York Historical Society. This important papyrus remained untouched with no further inquiry into its secrets until 24 years later. In 1930, the papyrus was "rediscovered" and turned over to James Henry Breasted, an American Egyptologist and archeologist. Breasted translated the papyrus from the original in the possession of the New York Historical Society, and published a new limited edition. ${ }^{8}$ The Edwin Smith papyrus is now part of the collection of the New York Academy of Medicine.

Forty-eight cases are discussed in the Smith papyrus, including those involving injuries to the spine and cranium. Each case includes a diagnosis followed by a progno- 


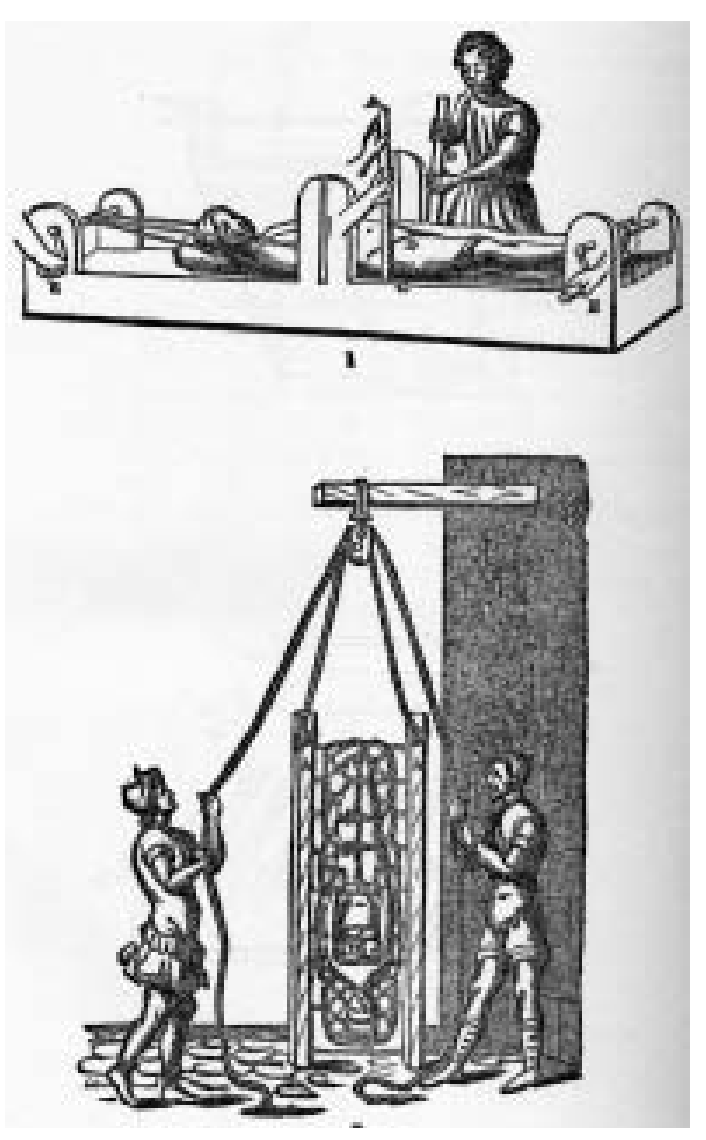

FIG. 5. Illustration showing the Hippocratic treatment of spine injuries - the rack system and the technique of using gravity being used to straighten the spine. Reprinted from Hippocrates: The Genuine Works of Hippocrates (translated by Adams F). London: Sydenham Society, 1844, Vol 2, pp 117-118.

sis. Other than from the isolated cases found in the remaining papyri fragments, little can be gleaned from them on the actual practice of surgery and, in particular, surgery of the cervical spine. It is clear from reviewing these early cases that a direct surgical approach was almost never recommended, and that the fear of Hammurabi and his code was clearly a factor in these decisions. The concept of intradural surgery during this period appears to be even more remote, and most surgery was likely extradural, that is, confined to removing bone fragments or other objects compressing the spine. Not surprisingly, early writers advocated stabilizing the injured segment and letting nature take its course. ${ }^{8,18}$ The Egyptian physician clearly recognized spine injury as a serious problem with an outcome almost always fatal.

The papyrus reveals a good amount of ancient Egyptian knowledge about the heart and its relationship to the pulse. Further discussed are the Egyptian concepts of the functions of the stomach, bowels, and vascular system. For the neurosurgeon or surgeon it is interesting that most of the cases involve topics of neurosurgical interest. We find in the papyrus some of the oldest descriptions of the brain, CSF, meninges, skull, and cranium. Concerning the history of cervical spine injury, this papyrus remains the earliest and most complete medical document providing

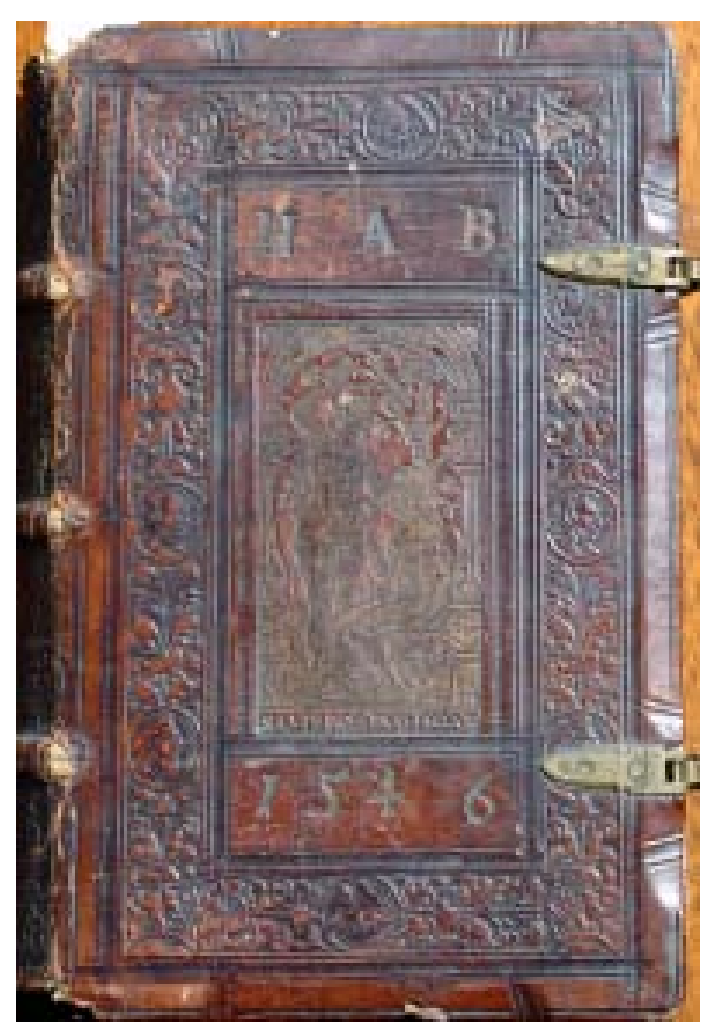

FIG. 6. Photograph of an early edition (1542) of Celsus in a fine dated binding with a typical allegorical religious panel on the front board.

insight into the diagnosis and management of cervical spine trauma. In addition to direct observations of trauma and anatomy, the Egyptians were surprisingly observant in discussing relationships between injuries of the brain and spinal cord and their functional consequences in other parts of the body.

To provide the reader with some insight into this most remarkable document and this early period of surgical practice, we summarize several of the cases dealing with cervical spine trauma as translated by Breasted in his 1930 classic work. ${ }^{8}$ The syntax and spelling in these summaries are those of Breasted. What may interest the modern reader are the types of wounds, the clinical findings, and more importantly, the treatment (or lack thereof) that was recommended. Unfortunately, "An ailment not to be treated" was the most common form of treatment recommended for a serious injury to the cervical spine. Recognizing the lack of antisepsis, anesthesia, and good neurological localization, as well as the implications of Hammurabi's Code, the evident frequency of recourse to this form of treatment is understandable.

Case Twenty-Nine: Instructions concerning a gaping wound in a vertebra of his neck.

Examination: If thou examinest a man having a gaping wound in a vertebra of his neck, penetrating to the bone, and perforating a vertebra of his neck; if thou examinest that wound, and he shudders exceedingly, and he is unable to look at his two shoulders and his breast ...

Diagnosis: Thou shouldst say concerning him: "One having a wound in his neck, penetrating to the bone, perforating a ver- 


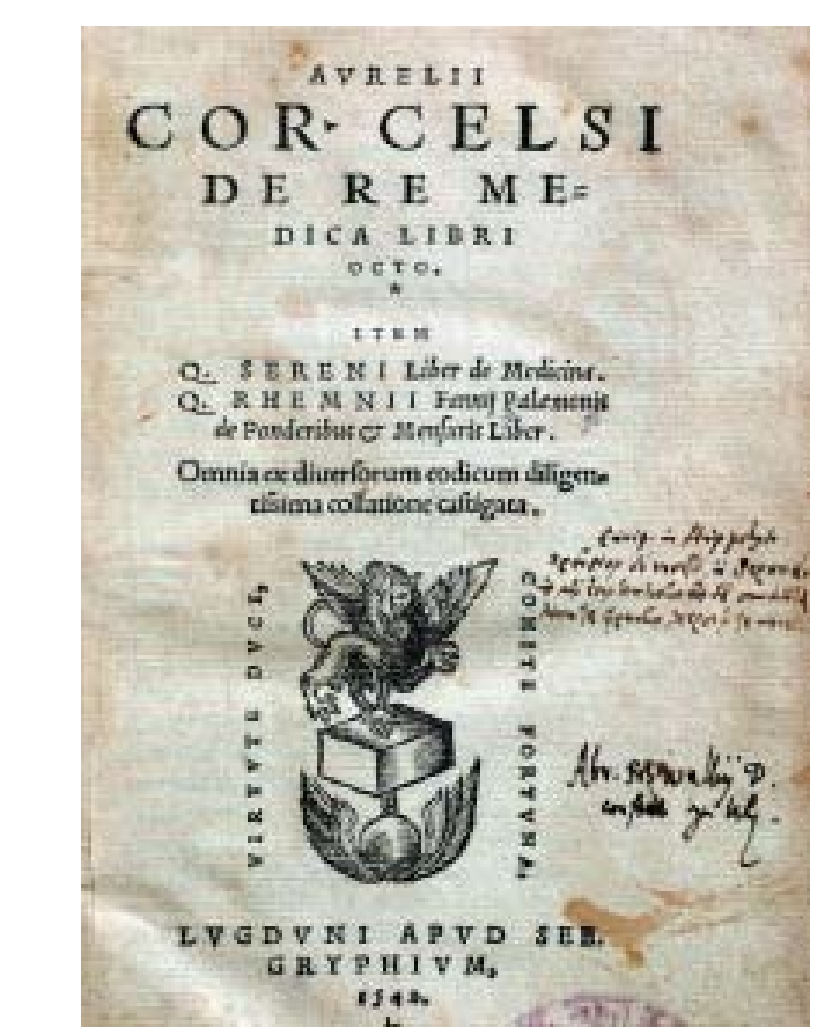

Fig. 7. Title page from the work of Celsus (shown in Fig. 6). Early annotations on the title are from a contemporary owner.

tebra of his neck, and he suffers with stiffness in his neck. An ailment with which I will contend."

Treatment: Thou shouldst bind it with fresh meat the first day. Now afterward moor him at his mooring stakes until the period of his injury passes by.

Case Thirty: Instructions concerning a sprain in a vertebra of his neck. Examination: If thou examinest a man having a sprain in a vertebra of his neck, thou shouldst say to him: "look at thy two shoulders and thy breast." When he does so, the seeing possible to him is painful.

Diagnosis: Thou shouldst say concerning him: "One having a sprain in a vertebra of his neck. An ailment which I will treat."

Treatment: Thou shouldst bind it with fresh meat the first day. Now afterward thou shouldst treat with honey every day until he recovers.

Gloss: As for: "A sprain" he is speaking of a rending of two members.

Case Thirty-One: Instructions concerning a dislocation in a vertebra of his neck.

Examination: If thou examinest a man having a dislocation in a vertebra of his neck, shouldst thou find him unconscious of his two arms and his two legs on account of it, while his phallus is erected on account of it, and urine drops from his member without his knowing it; his flesh has received wind; his two eyes are bloodshot; it is a dislocation of a vertebra of his neck extending to his backbone which causes him to be unconscious of his two arms and his two legs. If, however, the middle vertebra of his neck is dislocated, it is an emissio seminis which befalls his phallus.

Diagnosis: Thou shouldst say concerning him: "One having a dislocation in a vertebra of his neck, while he is unconscious of his two legs and his two arms, and his urine dribbles. An ailment not to be treated."
[Glossary: As for: "A dislocation in a vertebra of his neck," he is speaking of a separation of one vertebra of his neck from another, the flesh which is over it being uninjured (Fig. 1 and 2).]

Case Thirty-Three: Instructions concerning a crushed vertebra in his neck.

Examination: If thou examinest a man having a crushed vertebra in his neck and thou findest that one vertebra has fallen into the next one, while he is voiceless and cannot speak; his falling head downward has caused that one vertebra crush into the next one; and shouldst thou find that he is unconscious of his two arms and his two legs because of it.

Diagnosis: Thou shouldst say concerning him: "One having a crushed vertebra in his neck; he is unconscious of his two arms and his two legs, and he is speechless. An ailment not to be treated."

[Glossary: As for: "His falling head downward has caused that one vertebra crush into the next," it means that he has fallen head downward upon his head, driving one vertebra of his neck into the next.]

Case Forty-Eight: Instructions concerning a sprain of a vertebra in his spinal column. Examination: If thou examinest a man having a sprain in a vertebra of his spinal column, thou shouldst say to him: "Extend now thy two legs and contract them both again." When he extends them both he contracts them both immediately because of the pain he causes in the vertebra of his spinal column in which he suffers.

Diagnosis: Thou shouldst say concerning him: "One having a sprain in a vertebra of his spinal column. An ailment which I will treat."

Treatment: Thou shouldst place him prostrate on his back

The Edwin Smith papyrus remains one of the most sig-

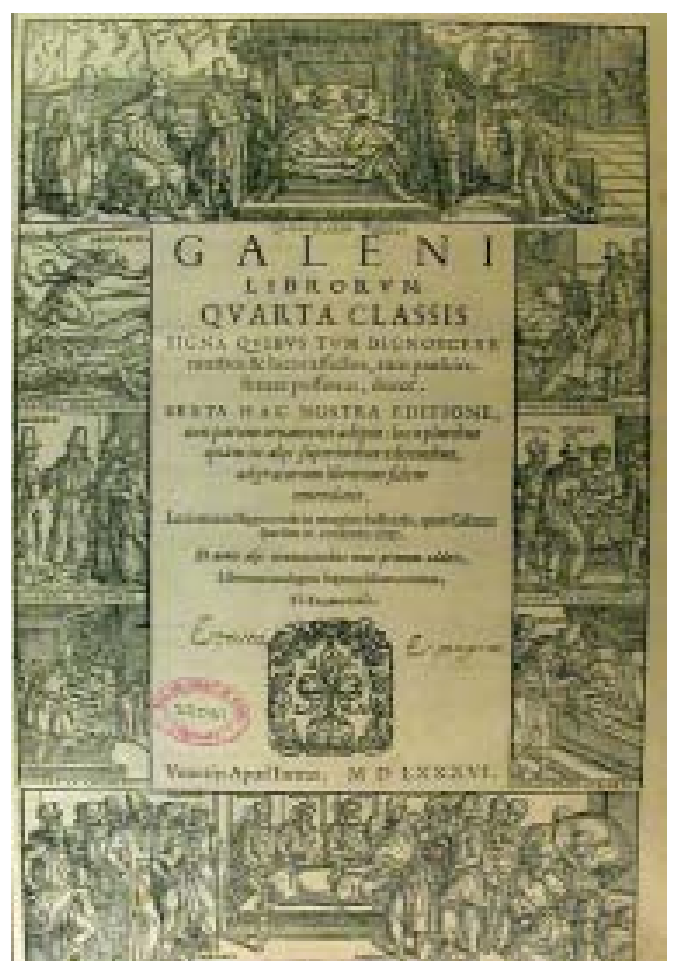

FIG. 8. Photograph of an allegorical title page from the collected works of Galen showing a number of historical figures in the panels. Reprinted from Galen of Pergamon: Omnia quae extant opera in Latinum sermonem conversa. Venice: Apud haeredes Lucaeantonii Juntae, 1576-1577. 


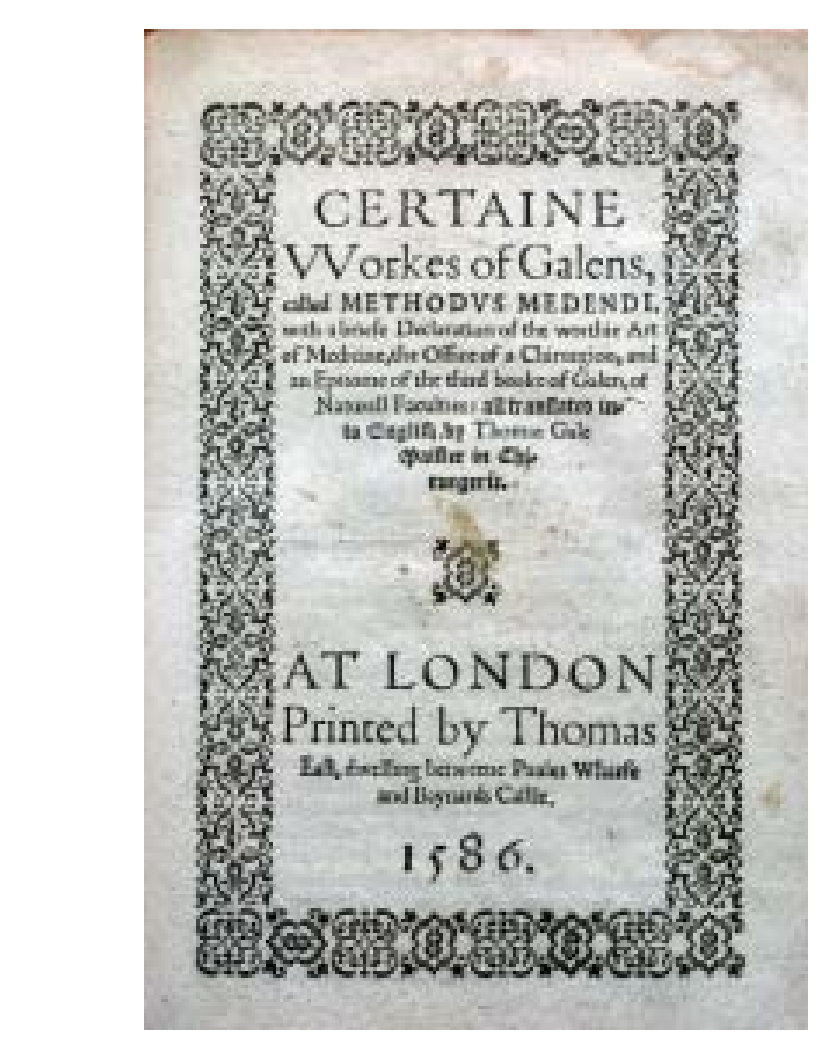

FIG. 9. Title page from an early 17 th-century English translation of Galen, including his advice to surgeons. Reprinted from Thomas Gale: Certaine Workes of Galens. London: Thomas East, 1586.

nificant medical texts ever discovered. Although valuable to the scientific and nonscientific world, as noted, because of its antiquity and general relevance as the earliest medical text, the papyrus is of particular interest and value to neurosurgeons because of its specific references to ancient neurosurgical cases. The descriptions of both brain and spinal cord traumas and infections, as well as their recommended treatments, would assuredly be applicable to the general population in ancient Egyptian times. The Edwin Smith Papyrus provides the modern neurosurgeon with a window in time in which he or she can wonder at the challenges and insights faced by their ancient Egyptian ancestors at the dawn of the medical profession.

\section{Greek and Early Byzantine Period: Historical Origins of Cervical Spine Surgery}

\section{Hippocratic School}

The intellectual evolution of neurological spine surgery originated in the golden age of Greece with the founding of the Alexandrian School in 300 BC. ${ }^{12}$ It was then that open dissection was incorporated into formal teaching, a significant step forward in learning surgical skills. During the Greek period there was no conception of the surgeon who, in the strict sense, restricted himself to the practice of "neurosurgery" or to only surgery of the spine. Spine and head injuries, however, appear to have been plentiful,

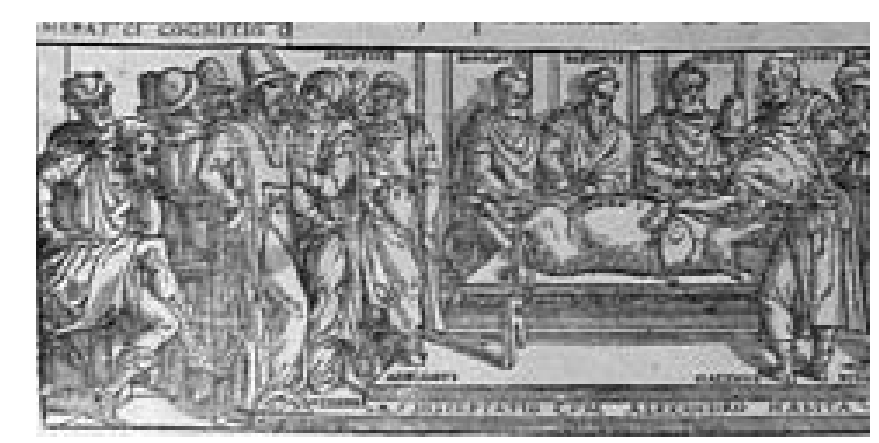

FIG. 10. Photograph of an allegorical scene of Galen cutting the recurrent laryngeal nerve of a pig. From the title page of Galen's work Opera Omnia. Reprinted from Galen of Pergamon: Omnia quae extant opera in Latinum sermonem conversa. Venice: Apud haeredes Lucaeantonii Juntae, 1576-1577.

owing to wars and internecine conflicts (as graphically recorded by the historians, Herodotus and Thucydides, if not also by Homer). War was then, and still remains, the primary source of material for the study and treatment of neurosurgical injuries. ${ }^{38,39}$ In the Iliad, Homer describes a fatal blow by Achilles, and afterwards describes an early outcome in cervical spine trauma:

Achilles, smiting him with the sword upon his neck, hurled afar his head and therewithal his helmet; and the marrow spurted forth from the spine and the corpse lay stretched upon the ground. (Book XX, lines 481-483) ${ }^{46}$

Homer continues in a further passage:

.. and Hector with his sharp spear struck Eioneus on the neck below the well-made helmet of bronze, and loosed his limbs. (Book VII, lines 11-12) ${ }^{46}$

The earliest medical writings from this period are generally thought to be those of Hippocrates (460-370 BC),

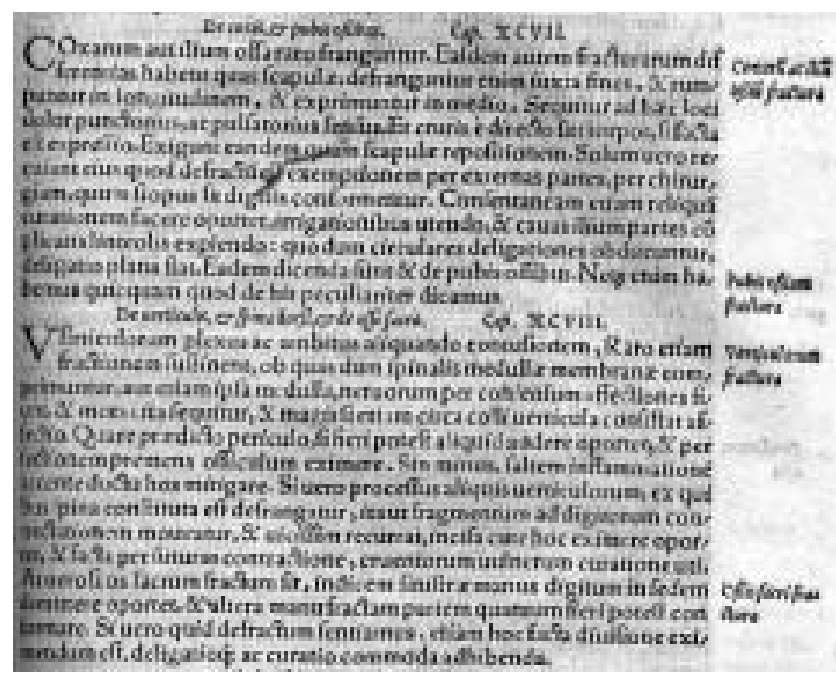

FIG. 11. Text from an early Latin publication in which Paul of Aegineta describes his treatment of a vertebral injury. Reprinted from Paul of Aegineta: Opus de re medica nunc primum integrum. Cologne: Opera et impensa Joannis Soteris, 1534. 


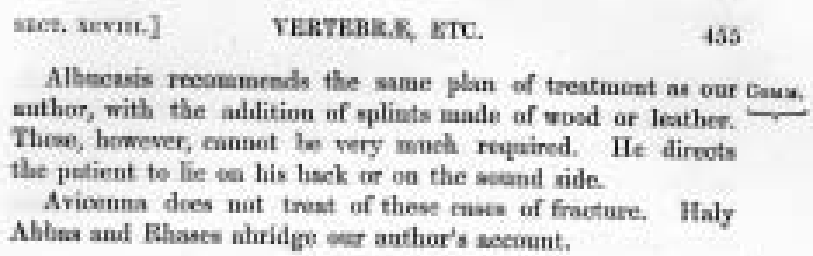

YERTBRER, KTC.

Albecasis reoommends the same plan of treatiuent an ouf Caus; suthor, with the aldition of splints made of wosd or leather. Thowe, bowever, conant he very moch reyuined. Ht dircots the patient to lie se his lask of on the soumd ride.

Arimuna deses nut trast of these mase of frooture. Haly Ahbisa and Rhases ahridge eser anthor's secount.

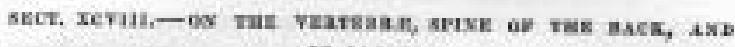
ca acher

The rownil bodies of the vertelure may somesimes be crushed, but muely undergo frneture, is which enses the mombranes of the suinal marrov of the marrow itself being compressed, sympathetie nervoes nffections take plave, and dendk poedily fallows, mare particularly if the rertuthe of the seck be nffocted. Wherefort, having first giren warning of the denger, we must, if possible, attempit to estract by as incivion the compnosing bone, er if not ve most soothe the part by the anti inflammatery treatmest. But if ang of the proessese of the vertebra, of which the spines, sa it ia ealled, consists, he booken off, it will rendily be felt upen examination with the fingor, the heoken pioev yielding and returning agmin to its pustion, and, there fore, we most make an incixiun of the stin estemally and extract it, and having unitnd the vound with matarea, pursoe the trestment for recent mounda. Whe the as sacram is fructered the index-finger of the len band is to be introdnced into the suus, while with the other ve manage as we bent enn the frecturul love; or if we feel any piree beoken ef, we malie an incisien and loy boll of it, and apply bnainges sat vuitable treatment.

Cosansesier. Celsus remarks that when a plece of one of Cows. the vertebine is broken off a bollow is. felt in the plarn, it is attended with pain, and the persese is compelled to bend inwands. The treatmest is to be sanilacted opon genernl jrin. eiples, as explained uniles fructares of the nopula.

Alhueasis lays it down as a rule that when a froeture of the cervical vertebme produces panalyais and iusensilility of the armas, the eswe moy be abandoned as hopelese. When, after a

FIG. 12. English translation of Paul of Aegineta's treatment of a spine column injury with bone fracture. Reprinted from Paul of Aegineta: Seven Books of Paulus Aegineta (translated by Adams F). London: Sydenham Society, 1844-1847.

the most celebrated of the Asclepiadae (Figs. 3 and 4). ${ }^{31,33}$ Hippocrates could trace his ancestry through 15 generations directly to Aesculapius. Classical philologists state that many of the writings attributed to Hippocrates were, in reality, composed by members of the Hippocratic School. ${ }^{3,31-33}$ The Hippocratic collection presented clinical cases based on observation, but only the simplest of theories are offered. The concept of a disease arising from an organic system was little understood, and disturbances in "humors" or of certain fluids in the body were prominent in the elementary Greek view of illness.

The Hippocratic writings contain numerous anatomical descriptions, even though human dissection was not routinely practiced. One drawback for the contemporary student of these writings was their lack of graphic illustration, compelling the reader to visualize and memorize his or her own "picture" of the anatomical description. The Greeks also lacked an anatomical vocabulary, which would not be introduced until Galen did so using the Latin language. These deficiencies combined to retard any stan- dardized anatomical procedures or practice of surgery. Despite these drawbacks, there are within the Hippocratic writings a number of interesting histories that do reflect practices related to spine injuries in this period.

A review of Hippocratic writings suggests that actual surgery on the spine was a great rarity. The practice of intradural exploration was most unlikely, given Hippocrates' conservative views on head injury and dural exploration. Stabilization of the spine with external splinting was the common form of conservative treatment; many of the more modern translations of his writings clearly illustrate some of the splinting designs. Penetrating injury to the spinal marrow was considered quite grave, with the resultant urinary retention categorized as a lethal injury. In an interesting tirade in his section on articulations, Hippocrates laments the presence of charlatans who would offer cures for spine injuries or treatments that were spurious at best (Fig. 5):

And the spinal marrow would suffer, if from the displacement of a vertebra it were to be bent even to a small extent; for the displaced vertebra would compress the spinal marrow, if it did not break it; and if compressed and strangled, it would induce insensibility of many great and important parts, so that the physician need not to give himself any concern about rectifying the displacement of the vertebra, accompanied, as it is, by many other ill consequences of a serious nature. It is evident, then, that such a case could not be reduced either by succession or by any other method, unless one were to cut open the patient, and then, having introduced the hand into one of the great cavities, were to push outward from within, which one might do on the dead body, but not all on the living.

Wherefore, then, do I write all this? Because certain persons fancy that they have cured patients in whom the vertebra had undergone complete dislocation forward. Some, indeed, suppose that this is the easiest of all these dislocations to be recovered from, and that such cases do not stand in need of reduction, but get well spontaneously, Many are ignorant, and profit by their ignorance, for they obtain credit from those about them. ${ }^{32}$

From this brief clinical note one can see that Hippocrates and his school clearly did not always favor surgical intervention for a spine injury. Injury of the cervical spine carried the gravest consequences and was to be approached with great trepidation and only by the most skilled surgeon or physician. Clearly recognizing the severity of these injuries, Hippocrates and his students recommended external stabilization and immobilization as the treatment of choice. Given that they were writing long before the advent of effective antisepsis and antimicrobials, the Hippocratic writers must have been aware of poor surgical outcomes due to infection. Taking note of the lack of effective anesthesia and analgesia, the modern surgeon can easily understand the conservative views of the Hippocratic school and subsequent generations of surgeons who preferred not to perform aggressive surgical interventions on the cervical spine.

\section{Herophilus of Chalcedon (335-280 BC)}

Following Hippocrates by about 65 years, from the region of the Bosporus, among the crowded schools of Alexandria, came Herophilus of Chalcedon, a pupil of Praxagoras and Chrisippus and a member of the educated 


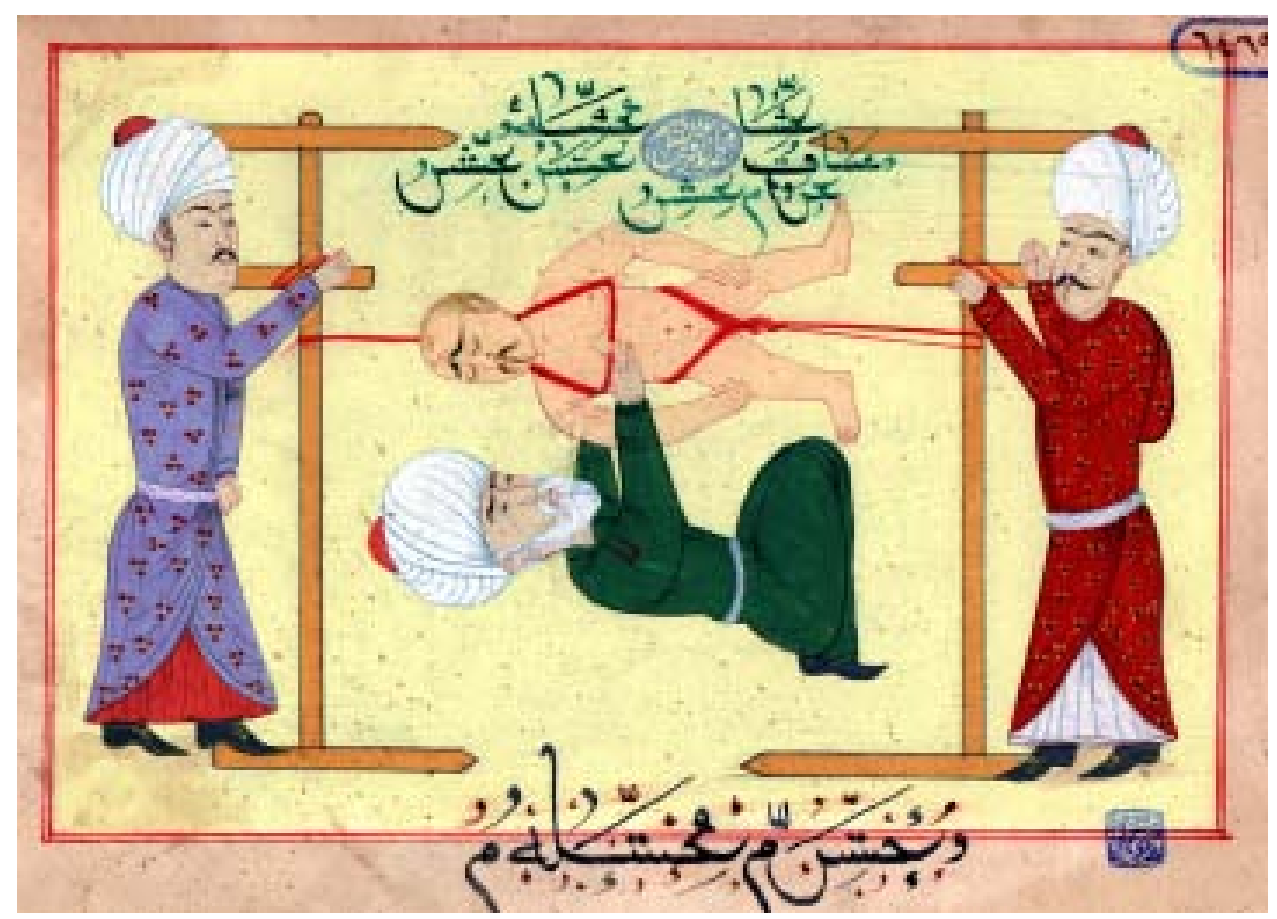

FIG. 13. Early anatomical scene from a manuscript based on Avicenna, which has been attributed to Serefeddin Sabuncuoglu, ca. early 18th century. From the author's personal collection.

dynasty of the Ptolemies. Herophilus was born in Chalcedon, a small town on the Asiatic side of the Bosphorus in what is now Istanbul, Turkey. ${ }^{12,30}$ In approximately 300 $\mathrm{BC}$, he moved to the great academic center in Alexandria, a cradle of learning in this era. Modern historians credit Herophilus with introducing human dissection as a routine practice. Unlike his predecessors, Herophilus is credited with dissecting humans (not just animals) more than 100 times, according to his own account. ${ }^{29}$ Herophilus also appears to have dissected living individuals - according to Celsus, Herophilus received live prisoners from kings "while breath still remained in these criminals." ${ }^{3}$ An account of Tertullianus referred to Herophilus and his efforts in dissection:

Herophilus cut up innumerable persons (six hundred people) in order to examine their nature, who hated humans, in order to have knowledge, explored their internal parts, but he probably did not explore all of them clearly, since death itself changes what has been alive, especially a death which is not a simple one but one which is an error in the minds of the artificial process of dissection. ${ }^{3}$

Whether Herophilus performed 100 or 600 dissections remains an open question. A significant further contribution by Herophilus was to engage in the arduous task of developing an anatomical nomenclature and forming a much needed language, or vocabulary, for anatomy. Current students use a rich and varied vocabulary to describe anatomy and anatomical concepts-many do not realize that the development of a "vocabulary" is a historically recent phenomenon, and that much of this development began with the great early anatomist, Herophilus. He also introduced the concept of "nerves" and nervous system

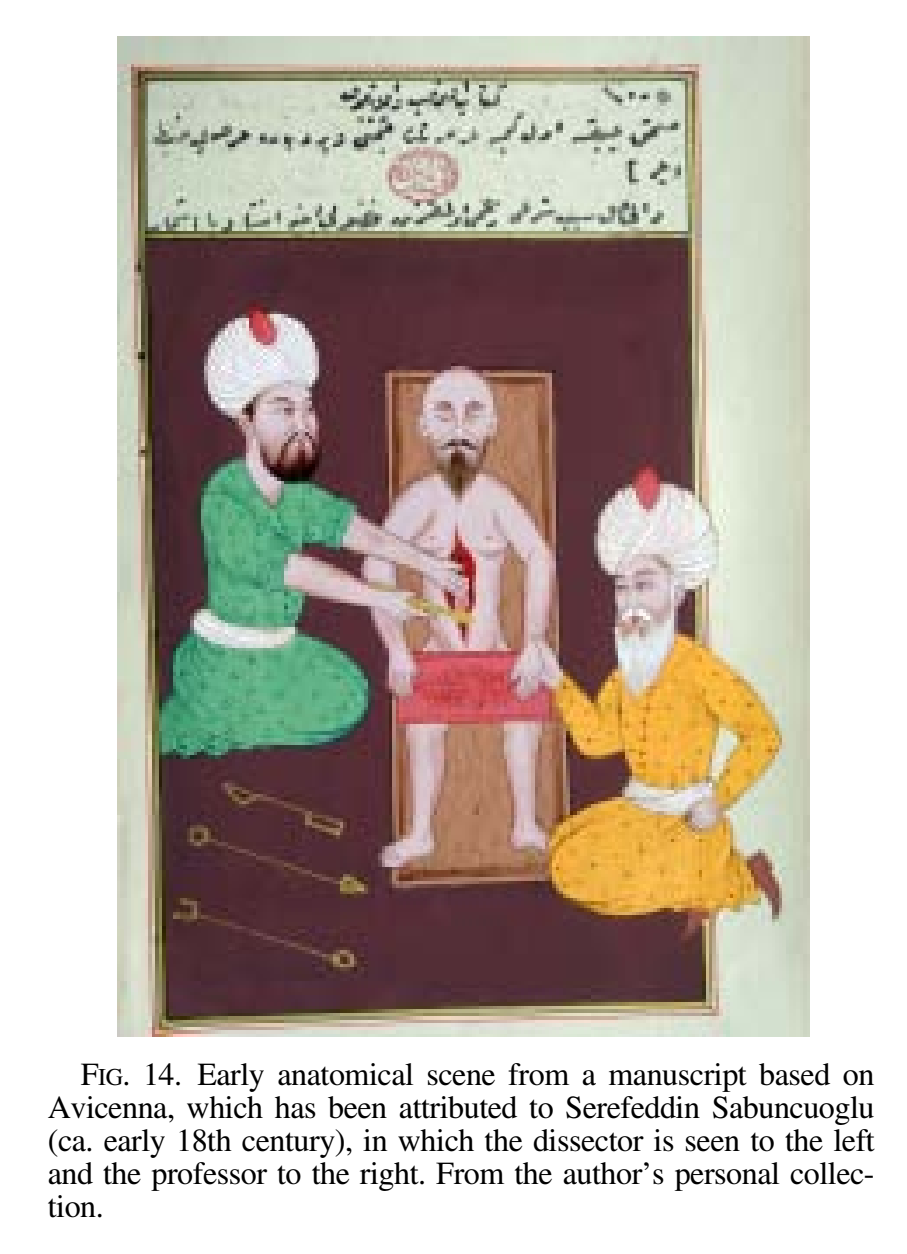

Neurosurg. Focus / Volume 23 / July, 2007 


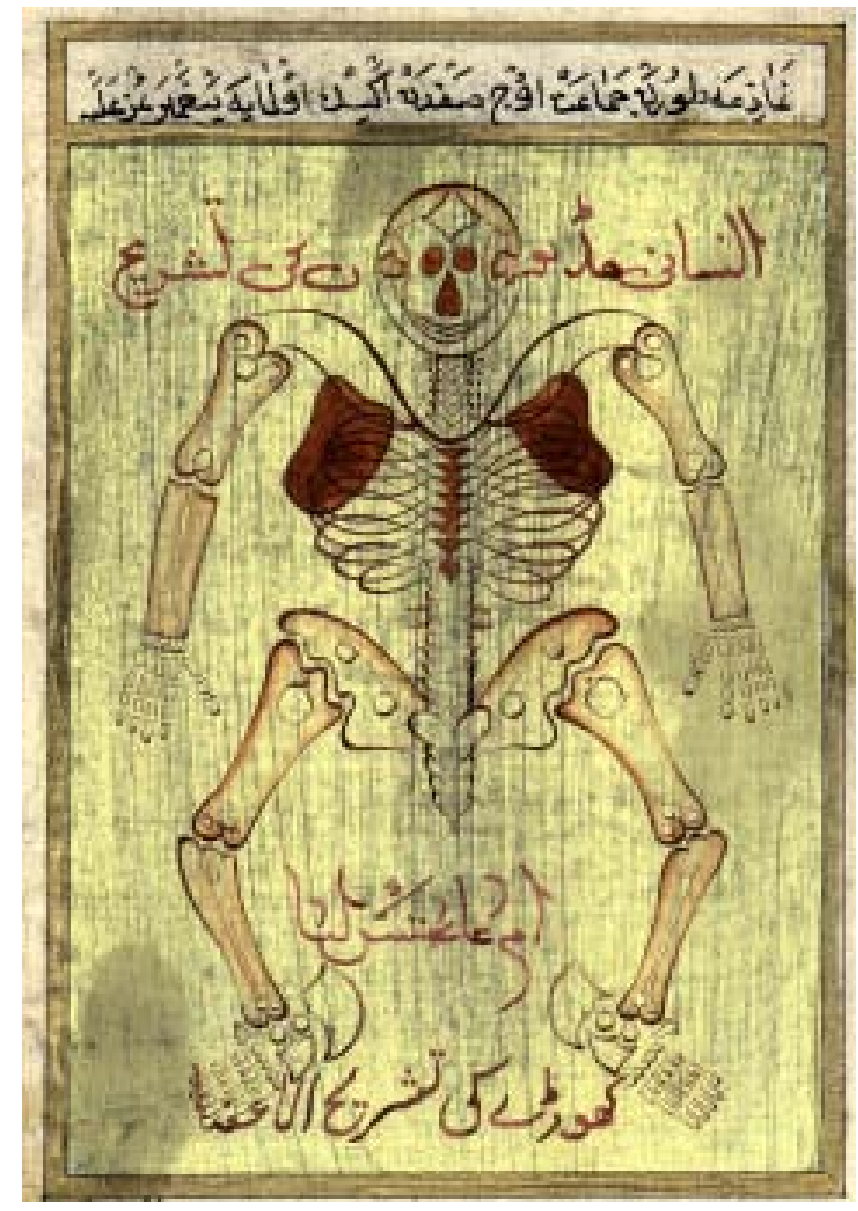

FIG. 15. The anatomy of the skeleton is represented in this early manuscript leaf from a work attributed to Avicenna. The early understanding of anatomy was quite primitive among the European and Arabic cultures. An early Arabic anatomical manuscript from the author's collection.

anatomy. In examining the nervous system, Herophilus traced the origin of nerves to the spinal cord anatomically and divided them into motor and sensory tracts, making a further important differentiation. It is not clear from his writings whether this determination was made on the basis of human vivisections, but it appears this was most likely the case, considering the wealth of anatomical material provided him. ${ }^{30}$ As a result of his studies he corrected a common error at the time, that of confusing nerves and tendons. Herophilus spent a great deal of time in anatomical research to rectify these common anatomical errors of the time. ${ }^{30,37}$

Among his contributions was the first descriptions of the ventricles and venous sinuses of the brain, and in particular the "confluents of the sinuses," also known as the Torcula Herophili $(\Lambda \alpha v o \zeta=$ wine press). From his writings it appears likely that he did not understand the concept of CSF, and such an understanding would not be revealed until the studies of Domenic Cotugno in the 18th century. Herophilus followed the teachings of the Hippocratic School, recognizing that injuries of the spinal column and to the spine marrow were almost invariably lethal or, at the very least, carried a dismal prognosis. As noted previously, this great anatomist and scholar performed some of the earliest known research on the spinal cord. Therefore, in accordance with a common belief of his era, Herophilus avoided any direct surgical invention on the cervical spine. Stabilization and removal of simple compression injuries were all that would be allowed.

\section{Aulus (Aurelius) Cornelius Celsus (25 BC-AD 50)}

Celsus was neither a physician nor a surgeon, but rather an intellectual patrician and a medical encyclopedist. His writings - which included an examination of the rival dogmatic, methodic, and empiric schools of medical thought-had an important early influence on surgery. These writings remain a valuable summary of the healing art for this period. As counselor to the emperors Tiberius and Caligula, Celsus was held in great esteem. His book, De Re Medicina ${ }^{10}$ is considered one of the most important early medical documents after the Hippocratic writings. Because his work was lost for a time, he was one of the few major authors not to be transcribed by Arab translators. It was not until 1443, when an early Celsus manuscript was uncovered by Thomas Sarazanne (later Pope Nicolas V), that his work could be reintroduced to the medical community. With the introduction of movable type, his De Re Medicina became the first medical manuscript to be printed in $1478 .{ }^{10}$ Indeed, its publication antedated the printing of works by Hippocrates and Galen. In Book 4, Chapter 10, we find his classic description of inflammation: "notae vero inflammationes sunt quattuor, rubor, et tumor, cum calore et dolore."11

Celsus combined a judicious application of medical theory with the everyday practical aspects of medicine; in his writings is clearly demonstrated an admiration for the Asclepiadae of Bithynia, an active group of medical practitioners in Rome circa 90 to 60 BC..$^{48}$ Little recognized by modern scholars are Celsus' contemporary discussions of human vivisection and a number of anatomical discoveries. In Celsus' De Re Medicina in the Prooemium (23-25) is a clear description of criminals provided by the kings for anatomical studies; Celsus writes, "and, still with breathing going on, they would inspect things which Nature had previously enclosed: their place, color, shape, size, arrangement, hardness, softness, which things touched other things and then the continuations and secluded spots of each of them and whether anything is mingled with another." ${ }^{48}$ Later in this work Celsus comments: "As many imagine, it is not cruel to sacrifice a few criminals to seek cures for the blameless people of the time." ${ }^{\prime 4}$ (Figs. 6 and 7).

In the field of spine surgery Celsus made a number of interesting early observations, but the most relevant one was his recognition that a cervical spine fracture could lead to vomiting and difficulty in breathing, and not uncommonly to death. ${ }^{10,11}$ Injury to the lower spine, on the other hand, he demonstrated could cause weakness or paralysis of the leg, as well as urinary retention or incontinence. Again following earlier Hippocratic views, Celsus rarely recommended surgical intervention, but rather immobilization and stabilization as the key to a good outcome. If urinary incontinence or retention developed, he believed the situation had become quite grave. Therefore, 


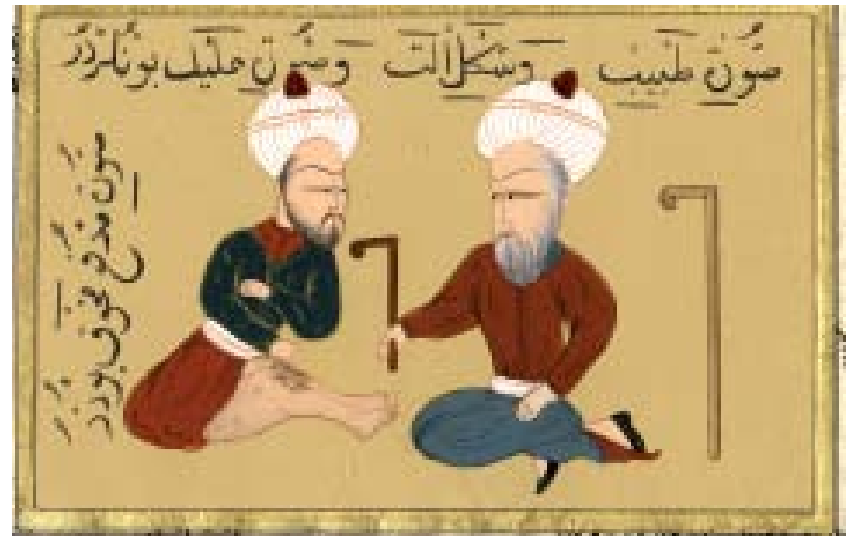

FIG. 16. Example of the application of the cautery for the treatment of wounds and bleeding. Manuscript attributed to Serefeddin Sabuncuoglu, ca. early 18th century; from the author's personal collection.

a theme that was first found with the Egyptians remained a common one through this era: the surgeon's fear of losing his hand remained real.

\section{Galen of Pergamon (129-200)}

Galen of Pergamon's name is derived from "galenos," which means calm or peaceful. In contrast to his name, he is mostly remembered as a contentious and often bitter controversialist. Galen was born in AD 129 (or possibly AD 131) in Pergamon, in what is now part of Turkey. This part of the world was a flourishing center for Hellenistic culture, a culture that was to have an enormous influence on Galen. According to legend, Galen's father, Nikon, was inspired by a dream in which Aesculapius appeared, son of Apollo and then patron of the medical arts. Nikon was told by Asclepius to have his son educated and trained in the practice of medicine..$^{53,55}$ From this dream emerged a powerful personality who became an original investigator, compiler, and codifier, as well as a leading proponent of the doctrines of Hippocrates and the Alexandrian school. Galen began writing at the age of 13 and continued to do so until he died at the age of 70 years. His collected writings overwhelm others of early antiquity in size, scope, and influence. ${ }^{7,19}$ Even if we were to eliminate his book Corpus Hippocraticum, Galen's prodigious output would still represent $80 \%$ of all the surviving medical writings of antiquity. A modern edition of his work comprises 22 thick octavo volumes (Fig. 8 and 9). ${ }^{20}$

Galen had the good fortune to live during the reigns of two of the greatest Roman emperors, Antoninus Pius (136-161) and Marcus Aurelius (161-180). As physician to the gladiators of Pergamon, Galen had access to a plethora of human material, both alive and dead, particularly patients requiring attention for traumatic injuries acquired in gladiator sports. These surgical activities, together with his scientific studies, enabled him to make a wide range of contributions to neuroanatomy and neurosurgery. His literary production is believed to have been almost 400 works, but unfortunately fewer than 100 treatises are known. ${ }^{54}$ Among his important surviving writings are his studies on Anatomic Procedures. ${ }^{19,21,22}$ Among the anatomical experiments he is known to have performed was transection of the spinal cord, which is well described in the ninth book of the Anatomic Procedures. With the results from this experiment Galen could accurately describe loss of function below the level of the lesion. Galen was among the first to describe the sum and substance of the spinal cord, in his 13th book. ${ }^{21}$ Modern antivivisectionists would be horrified to read of the experiments conducted on living animals in this work. Galen clearly describes the level of the spinal lesion and the resultant neurological outcome: ${ }^{16,23,56}$

You can perform this procedure without removing bone in new-born kids, dogs or pigs . . . try to introduce the knife precisely into the space between two vertebrae. In this regard you must pay attention to the tip of the bony pin of each vertebra. The hinge-like part between two vertebrae lies exactly on the middle of this region. After having cut this hinge and deepened the knife down within the spinal cord, you must move the instrument by pressing with your hands and swinging to the right and the left, so as not to leave portions of the cord incompletely cut. As a result, all nerves below the level of the transection lose both their faculties, namely the faculty of sensibility and the faculty of movement. Therefore, all parts of the body of the animal, where these nerves spread, become lacking in sensibility and movement. ${ }^{56}$

Among Galen's anatomical studies is the now classic experiment in which he sectioned the recurrent laryngeal nerve of a dog and described clearly the hoarseness that was a consequence of this surgical injury. ${ }^{19}$ Galen also made the first recorded attempt at identifying and numbering the cranial nerves. He demonstrated 11 of the 12 cranial nerves, but by combining several, he arrived at a total of only seven. Galen discarded Hippocrates' notion that the brain is only a gland, and attributed to it instead the powers of voluntary action and sensation, information that was further carried through the spinal cord from the brain, a considerable conceptual advance. Of additional interest to Galen was seeking knowledge of the structure and functions of organs, and these investigations led to his

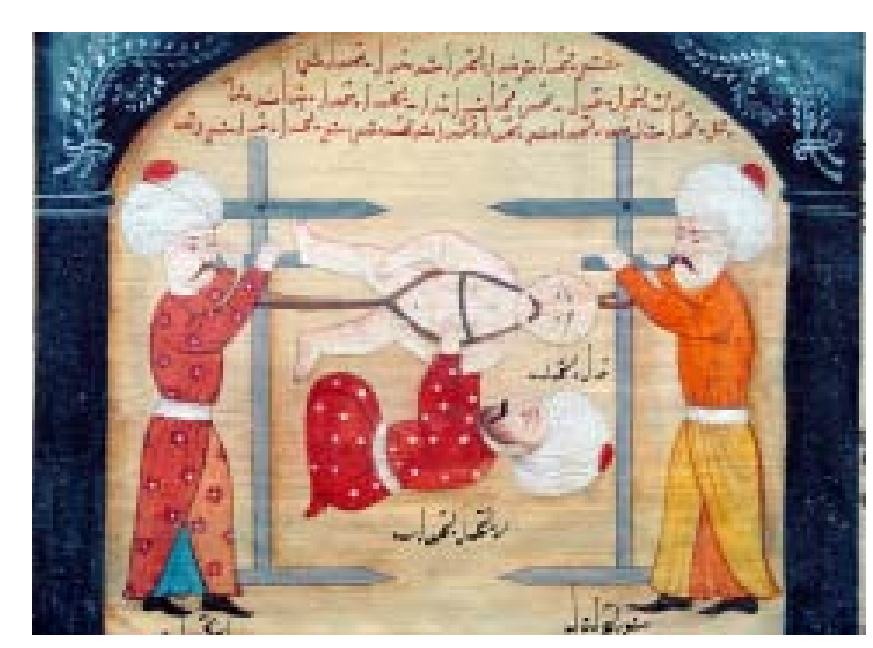

FIG. 17. Illustration showing the use of a rack to straighten the spine. From an early manuscript (attributed to Serefeddin Sabuncuoglu, ca. early 18th century) on the subject of Avicenna and the treatment of spine injuries. In the author's personal collection. 


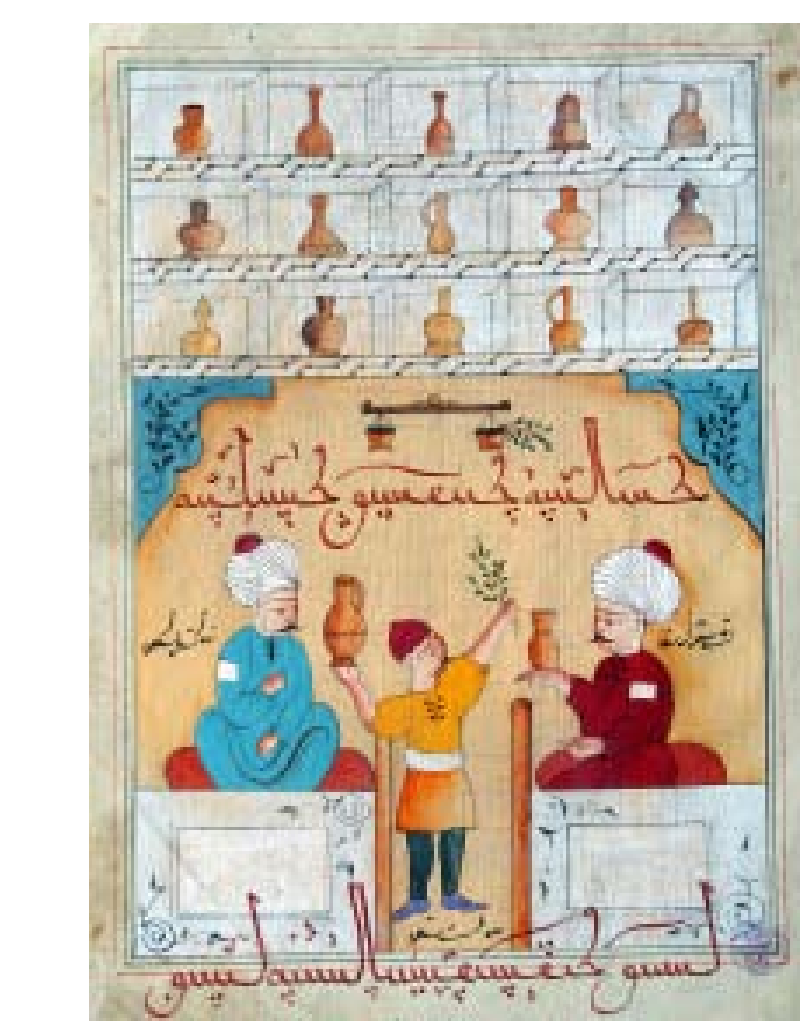

FIG. 18. Illustration showing a visit to the pharmacy by a physician to get counseling on drugs (apothecary medicines), and as noted in the top panel, advice on a urinalysis. Avicenna's Canon contains extensive discussions on pharmacy, medications, and urinalysis, among other subjects. From the author's personal collection.

localization of diseases to specific organs, a notable advance for the time (Fig. 10).

In neurology, too, Galen made a number of critical observations. He recognized that an upper cervical injury caused a disturbance in arm function. Transecting the spinal cord at C-2 or higher caused a total loss of sensation and motor control from the arms downward..$^{21,22,56}$ Injury to the middle or lower cervical spine was demonstrated by a series of cord transections, with the results such as paralysis of the chest muscles clearly described, among other findings. For the contemporary spine surgeon, it is noteworthy that Galen is remembered for coining the words "kyphosis, lordosis, and scoliosis." 19 He was among the first to describe Pott disease of the spine and attributed it to caries in the spine from tuberculosis. In the clinical management of the patient Galen introduced the "blow bottle" for breathing and lung exercises, and advocated loud singing in an effort to encourage deep breathing and a good pulmonary toilet in the treatment of spine injuries. In an experiment involving spinal cord injury, Galen provided details of a case of what today is known as Brown-Séquard syndrome, that is, a hemiplegia with a contralateral sensory loss in a patient in whom there is a hemisection of the cord. ${ }^{16,20}$ As a result of his vast surgical experience, Galen was much more liberal in advocating surgery than his contemporaries: he offered arguments for elevation of depressed skull fractures, fractures with he- matomas, and comminuted fractures, while also recommending the removal of bone fragments, particularly those pressing into brain and spine.

The Roman and later the Byzantine world would accept Galen's authority without reservation, conferring the status of medical dogma on his writings for nearly 16 centuries. ${ }^{43,50}$ Of great scientific concern was the absence of any followers or imitators to carry on his investigative work; for all practical purposes ancient science ceased altogether after he died and remained quiescent until the Renaissance. Consequently, along with Galen's death also came the demise of any further anatomical investigation of the nervous system for many centuries. Galen was to be held in too high an esteem by later writers, and was almost canonized by the Arab and medieval physicians. Generally speaking, Galen's anatomical studies were well thought out, and he clearly made a number of new and important discoveries. Yet as can happen in any investigative science, several errors crept into his work (for example, rete mirabile), which took time to correct. Approximately 14 centuries passed before many of these errors, carefully repeated by subsequent Arab and medieval physician and scribes, were finally rectified. The perpetu-

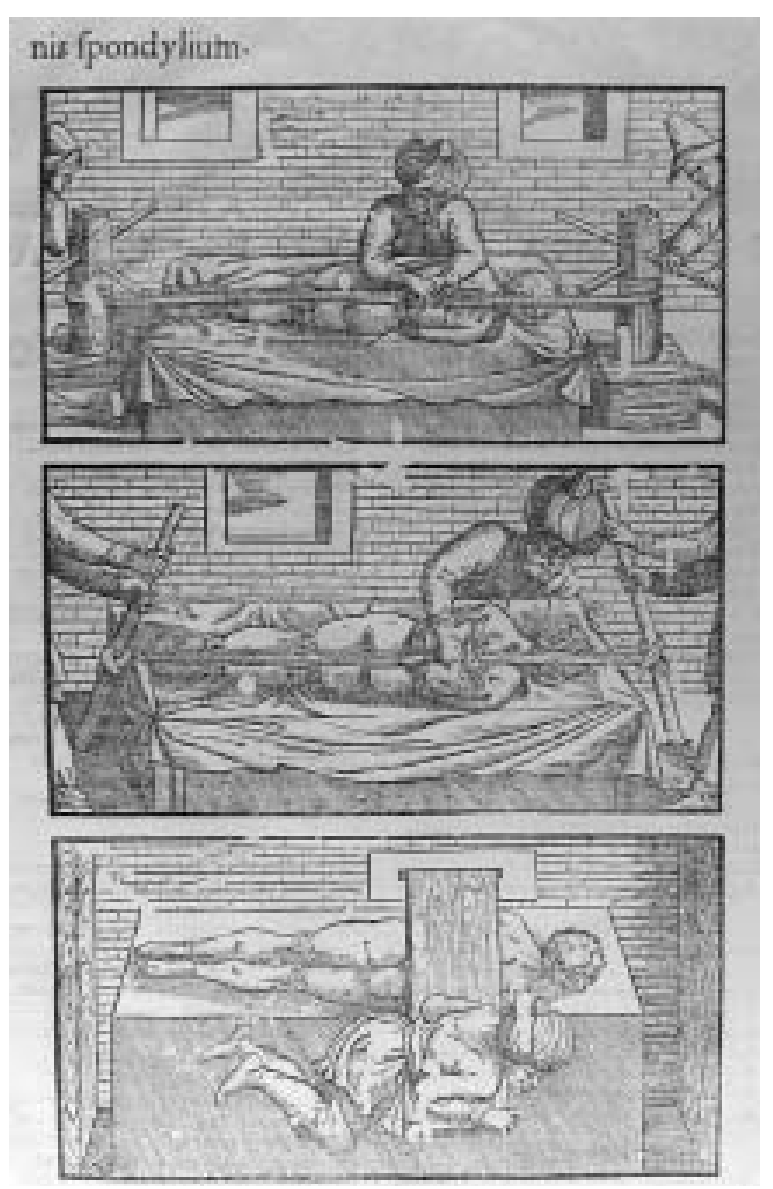

FIG. 19. An early printed example of the treatment of spine injuries in a work by Avicenna. Illustrated here are some of the examples of spine stablization. From Avicenna: Liber Canonis, De Medicinis Cordialibus, et Cantica. Basel: Per Joannes Heruagios, 1556. 
ation of such mistakes had a stultifying effect on new anatomical studies, which would not be undertaken again until the Renaissance.

\section{Paul of Aeginata (625-690)}

Paul of Aeginata was educated in the Alexandrian school and is among the last of the great Byzantine era physicians. He was an influential compiler of works in both the Latin and Greek schools, and his writings were routinely consulted well into the 17th century. His skill as a surgeon, moreover, drew patients from far away. Although Paul venerated the teachings of the ancient scholars as tradition required, he also introduced his own techniques with some remarkably good results. His classic work, Seven Books of Paul of Aeginata, contains an excellent section on head and spine injury. ${ }^{41,42}$

Several of Paul's earlier manuscripts have survived, in which he describes a number of instruments that he designed for neurosurgical procedures: elevators, raspatories, and bone biters all originated in this period. Paul classified skull fractures into several categories: fissures, incisions, expressions, depressions, and arched fractures. Paul was responsible for describing some of the earliest surgical techniques for dealing with injuries to the spine, and in particular the cervical spine. He was an early advocate of spine surgery in cases in which there was a known spine lamina fracture. In cases in which the surgeon thought there might be a laminar fracture with subsequent cord compression, Paul argued that a spine decompression (a laminectomy) was in the best interest of the patient. Paul was also among the earliest surgeons, if not the first, to routinely perform a laminectomy for traumatic injuries. In addition to his skills in surgical management, his wound management skills were also remarkably advanced for the period. He routinely used wine in his surgical dressings and wound care, a form of treatment that would be helpful in antisepsis, although this concept was unknown at the time. A further testament to Paul's skills as a surgeon is revealed in his writings, where he stressed that dressings applied to the spine (and the brain) should be applied with no compression, a simple but elegant surgical observation (Figs. 11 and 12).

The Roman and early Byzantine period clearly proved to be an era of scholarship and original investigation and produced physicians and surgeons who were intensely interested in learning better surgical and medical management protocols for their patients. As we have seen, individuals like Galen of Pergamon, Paul of Aeginata, Herophilus, and members of the Hippocratic School all attempted to improve the management of spine injuries and, at the same time, develop a better anatomical understanding of spine function. Although it remains a matter of intense debate for recent scholars, the teaching of human vivisection was clearly evident and the procedure was applied routinely throughout this period. Unfortunately, as we shall observe in the next section, in the prescholastic period of the Arab and late Byzantine era, neurological investigation and the development of new surgical techniques all but came to a halt. Rather than search out new techniques, or at least adopt some of the surgical theories of the Alexandrian period, writers and practitioners of this

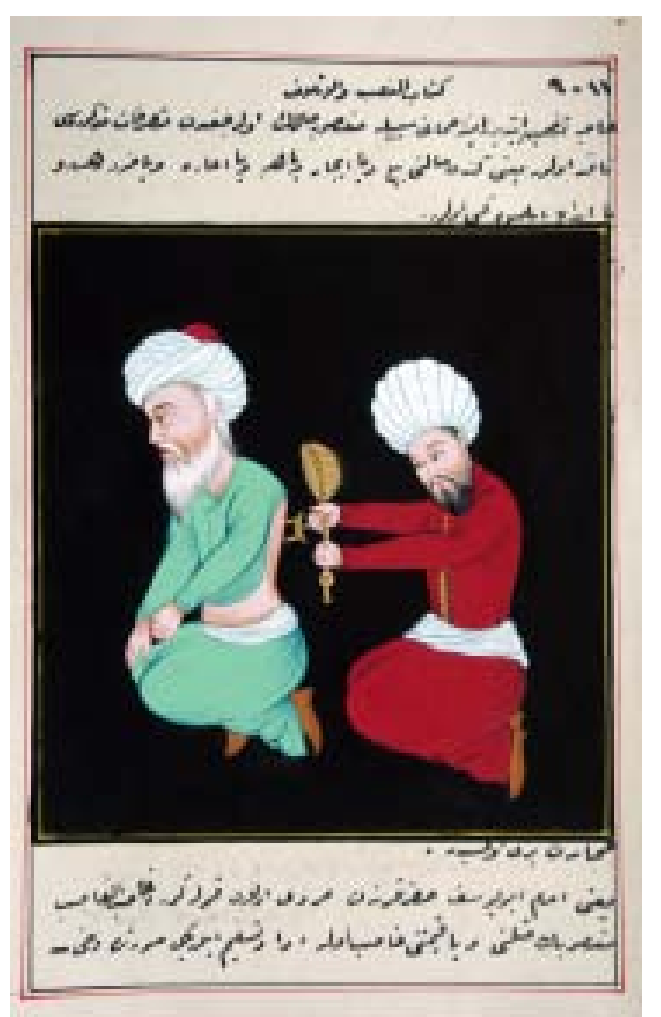

FIG. 20. An early printed example from Avicenna in which a form of an external spine stabilization is offered to a patient. Manuscript attributed to Serefeddin Sabuncuoglu, ca. early 18th century; from the author's personal collection.

period believed that the treatment of spine injury was all but hopeless. Again, the fear of losing one's surgical hand becomes prevalent in surgical thinking.

\section{Arabic Medicine: The Prescholastic Period (750-1200)}

After the great Greek and Roman periods of medicine, the intellectual centers of the discipline shifted to the Arab and late Byzantine cultures, whose influence was paramount from approximately AD 750 until 1200 . In contrast, Europe during this interval remained intellectually quiescent and unimaginative, overrun and ruled by "barbarians" (Huns, Goths, and Norsemen). This was a dormant period in all areas of surgery, and, in particular, in neuro- and spine surgery. The Koran specifically discouraged anatomical dissection, so for nearly 700 subsequent years the teaching of human dissection to the physician in the classroom was rare. The Arab schools, rather than developing new ideas of medical and surgical treatment, were satisfied with codifying the surviving manuscripts from the Greek and Roman period. Because of the incredible zeal of Arab translators, the best of Greek medicine was made available to readers of Arabic by the end of the 9th century.

An interesting but unfortunate rigid scholastic dogmatism became characteristic of the Arabic learning centers, and as copyists of the great works of antiquity translated from Latin, Greek, and Hebrew into Arabic, Persian, and 
other languages, the works became systematized and rigid in interpretation. Furthermore, copyists frequently added their own favorite view of the author and subject and sometimes would not reproduce the correct sense of the original writing. In fairness to these translators and codifiers, however, they did preserve the light of civilization, by maintaining the only camp of learning, whereas in Europe at this time the lamp remained unlit (Figs. 13 and 14).

It has often been stated that it is the Koran's religious influence that accounts for the absence of originality and progress in Arabic medicine, specifically because it has been said that the Koran discouraged or even forbade the practice of human dissection. Probably more important, however, is that the considerations of climate would be uppermost in extremely hot countries, where cadavers putrefy rapidly. Furthermore, because the Greeks and Alexandrians had already completed most of the anatomical

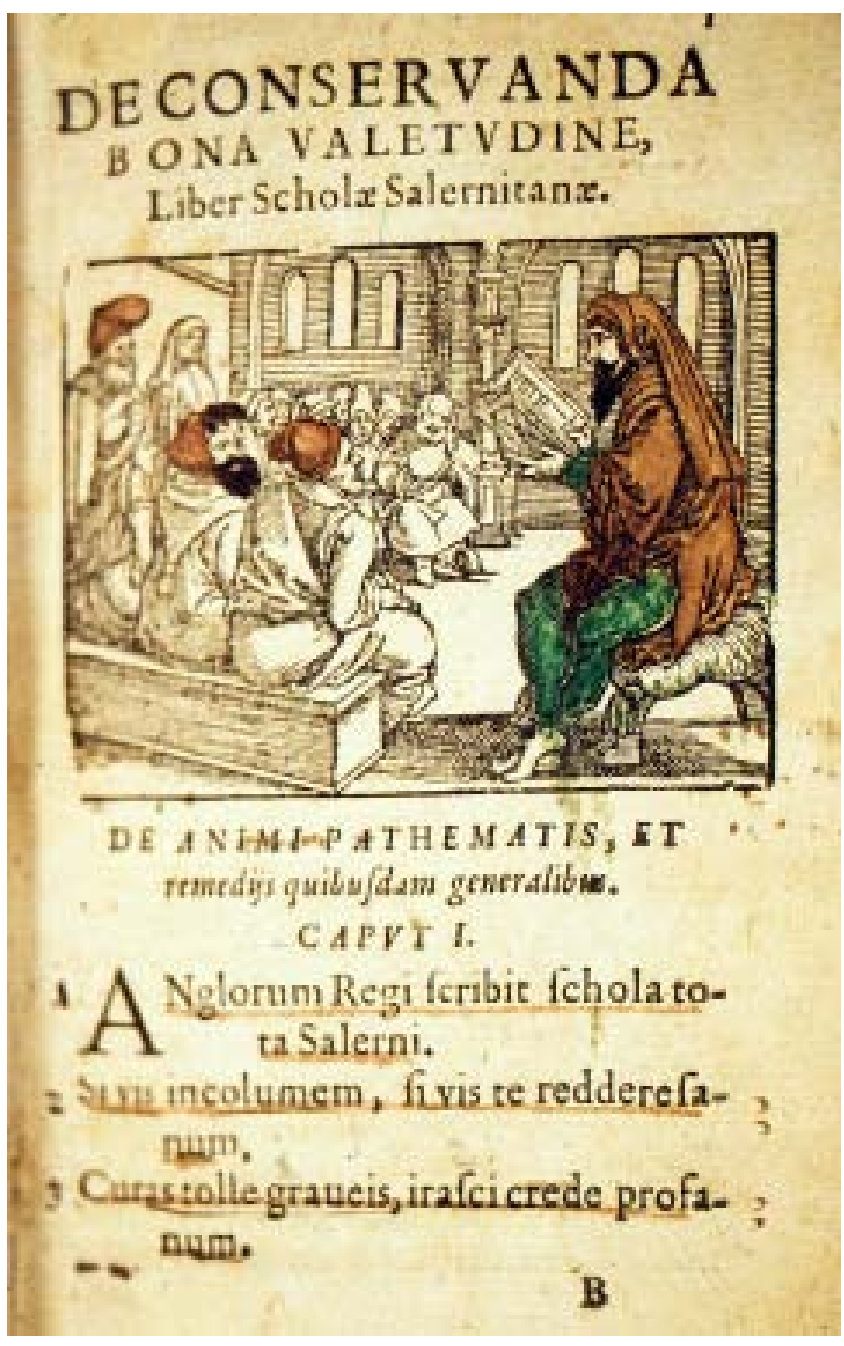

FIG. 21. An early illustrated work dealing with the school of Salerno. The cover shows Constantine the African lecturing to the school. From Anastasius, Arnaldus, Camerarius J, et al: Regimen sanitatis Salernitanum. Conservandae bonae valetudinis praecepta longe saluberrima, regi Angliae quondam a doctoribus scholae Salernitantae versibus. ... per Joannem Curionem ... France: Apud haeredes Christiani Egenolphi, 1573. studies of interest, the Arabic student of medicine saw no need to violate religious concerns by duplicating earlier efforts (Fig. 15).

The concept of a physician also functioning as a surgeon was not acceptable in the Arabic tradition of medical practice. Instead, it was expected that the physician would confine himself to writing learnedly, speaking ex cathedra, and assigning the menial tasks of surgery to an individual of a lower class. But lowering the class and educational level of the surgeon led to a situation in which mostly unskilled individuals, such as barber-surgeons, practiced surgery. The resultant outcomes can only be speculated upon, but most likely the results were poor. As a result of the belief that assigned surgery to individuals of a lower class, the advances in surgery and anatomy developed by the great Alexandrians, among others, were essentially ignored or lost. Nevertheless, the Arabic physicians of this period thrived from the 10th through the 12th centuries, despite the intellectual restrictions on new learning. Among the most illustrious scholars were Avicenna (980-1037), Rhazes (865-925), Avenzoar (died 1162), Albucasis (1013-1106), and Averroes (1126-1198). In reviewing their writings, one clearly finds an extraordinary effort to canonize the writings of their Greek and Roman predecessors. As a result, these Arabic scholars and physicians served as academics and guardians of what had become Hippocratic and Galenic dogma.

It should not be forgotten that Arabic medicine did introduce a great medical tradition, that of bedside medical care and teaching. From the point of view of the surgeon, the relative or complete lack of dissection and the practice of surgery (except by individuals of inferior status) inevitably diminished the value of any interest in surgical art. The only major contribution was the reintroduction of the Egyptian technique of using hot cautery to control bleeding, but its use in lieu of the scalpel to create a surgical incision proved a further unfortunate decision (Fig. 16).

\section{Rhazes (Abu Bakr Muhammad Ibn Zakariya al-Razl) (865-925)}

The writings of Rhazes reveal that he was a scholarly physician, learned in diagnosis and exclusively loyal to the Hippocratic teachings. Although primarily a court physician and not a surgeon, he nevertheless left writings on surgical topics that continued to be influential through the 18th century. ${ }^{43}$ Rhazes was one of the first physicians to introduce the concept of "concussion" and advocate surgery for penetrating injuries of the skull, even though he realized that patient outcomes were almost always fatal. He introduced the use of animal gut as a material for sutures and also provided us with one of the earliest descriptions of spina bifida.

\section{Avicenna (Ibn Sina) (980-1037)}

Avicenna, the influential Persian physician and philosopher of Baghdad (known as the chief or "second doctor" [the title of "first doctor" being attributed to Aristotle]), extended the Greek influence with a force so persuasive and durable that it still reaches us today. His writings were eventually translated into Latin and became a dominant presence in the major European universities well into the 


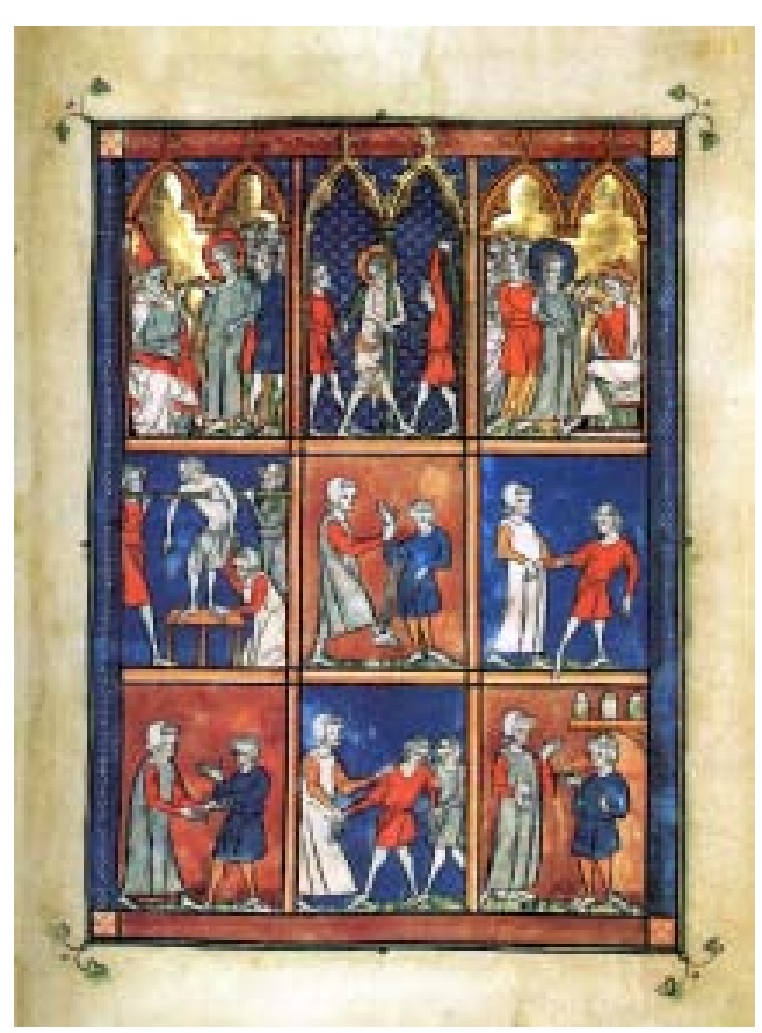

FIG. 22. An illustrated leaf from an important early manuscript on the works of Roger of Salerno. The concepts of "professor" and teaching within the Church guidelines are clearly evident here. Courtesy of the British Museum, Sloane Manuscript Collection. Manuscript No. 1977.

18th century. ${ }^{44}$ His major work, Canon medicinae (AlQanun fi al-Tibb), was an encyclopedic effort based on the writings of Galen and Hippocrates, wherein Avicenna's observations are mostly clinical, bearing primarily on materia medica. ${ }^{6}$ The Greek word Canon refers to a straight rod, a carpenter's rule, or a standard of measurement. As such, Avicenna's work became the rule, the codification or benchmark of Hippocratic, Galenic, and Greco-Roman medicine.

In his Canon medicinae a number of interesting neurological findings can be found. His greatest contribution must be the detailed translation of Galen's collected works, the Opera Omnia. Included within this work is one of the earliest and most famous illustrations of a series of spine stabilizations. ${ }^{6}$ Within the text are discussions of various spine injuries along with the prognoses. In less serious cases, the use of stabilization and even distraction is advocated to reduce and align the spine. Typically, the technique for performing such reductions requires the surgeon to place his knee anterior to the patient's neck and spine and apply pressure forward to achieve reduction and alignment. Despite his advanced thinking, Avicenna was often quite fatalistic in making the prognosis for these types of injuries. Rarely did he argue for surgical interventions because of the often dismal outcomes (Figs. 17-20).

In the fourth volume of the Canon, Avicenna presents a discussion of dislocations of the vertebrae along with their clinical presentations. ${ }^{6}$ Surgical intervention is occasional- ly recommended but in most cases stabilization and distraction are the rule: "It is an ominous sign if a vertebra dislocates completely or nearly completely. Spinal cord can be compressed by this displacement and its membranes may be ruptured. Even without any visible injury to the membranes the cord can be damaged and swelling in the cord may happen." 4 Avicenna was clearly aware that injury to the first cervical vertebrae was often lethal: "If the first cervical vertebra dislocates, the individual cannot breathe and dies immediately as the respiratory nerve is compressed and cannot function properly." 4 In discussing surgery of the cervical spine, Avicenna clearly adopted the thinking of Paul of Aeginata: "The management of vertebra fractures usually includes surgical intervention. In the operation the physician should remove the compressing bone that causes neurological deficit. If the crushed bone is removed even in part, the remaining bony chips must also be taken away as if taking out plant spines from the skin." Along with removal of the bone chips, Avicenna believed that careful exploration of the wound and spine marrow was necessary to remove any and all potentially dangerous objects. ${ }^{4}$

Avicenna did present some of the clearest anatomical descriptions of the cervical spine, along with concepts of function. Chapter eight of his Canon presents the anatomy of the cervical spine in some detail. The placement and details of cervical vertebrae $(\mathrm{C} 1-7)$ are given. The muscular and ligament attachments are clearly described along with their functional aspects. In describing the odontoid, he notes that it has two functions: "First, it is an efficient protector. Second, it prevents displacement of the thinner first cervical vertebrae." 39 The anatomical placement of each cervical nerve and its direction and innervations are clearly elucidated. The key question, for which we have no answer, is how much of the anatomy detailed by this Arabic scholar was codified from earlier writers, and how much came from his own clinical and anatomical observations? Recognizing Avicenna's intense scholarship, I would not be surprised to learn that many of the details came from original anatomical investigation, similar to how $\mathrm{Mi}$ -

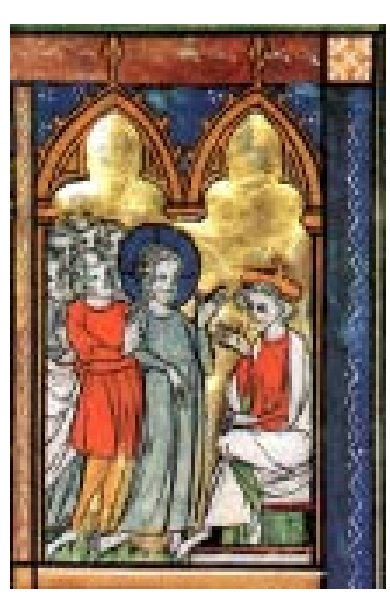

FIG. 23. An illustrated leaf from an important early manuscript on the works of Roger of Salerno. Illustrated here are some early surgical treatments, including some neurosurgical and spine treatments. Courtesy of the British Museum, Sloane Manuscript Collection. Manuscript No. 1977. 


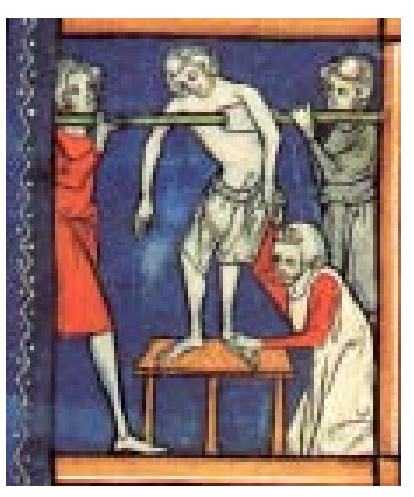

FIG. 24. An enlargement of one of the panels shown in Fig. 23 demonstrating treatment of a spine injury. The typical treatment consisted of using gravity and extension of the spine to treat a curvature. Courtesy of the British Museum, Sloane Manuscript Collection. Manuscript No. 1977.

chelangelo secretly did in monasteries approximately 500 years later.

\section{Albucasis (Al-Zahrawi) (936-1013)}

In the Arabic tradition, Albucasis was a great compiler as well as a serious scholar, whose writings (approximately 30 volumes) mainly focused on surgery, dietetics, and materia medica. One of his unfortunate accomplishments was to popularize the frequent use of emetics as prophylaxis against disease. This treatment has survived in the prescription of "purging," a debilitating treatment that continued as a European medical practice until well into the 19th century. On the other hand, his introduction to the Compendium presents an interesting discussion of why Arabic surgeons had made so little progress in surgery: he attributed this to a lack of anatomical study and inadequate knowledge of the classics. ${ }^{2}$

Albucasis was responsible for some of the original surgical techniques of this era. The final section of the Compendium consists of a lengthy summary of surgical practice at that time. ${ }^{1,2}$ Albucasis' work was also notable for featuring unique illustrations of surgical instruments. As a result of his writings, surgical techniques, and illustrations, this monograph was used extensively in the schools of Salerno and Montpelier and, hence, became an important influence in Europe during the medieval period. A number of the instruments featured were quite inventive and unique, and were original designs by Albucasis. The text clearly describes the surgical instrument's design, together with the technical aspects of their use. For neurosurgeons, his design of a conical "nonsinking" trephine is especially classic and provided the basis for the patterns of many later such instruments: it was designed with a collar on the trephine, placed in a circular fashion to prevent plunging into the brain. Some of the instruments Albucasis described were modeled on those described by Paul of Aeginata; the practical reputations of these tools were evidently enhanced by their inclusion in the Compendium..$^{1,2}$

Albucasis' treatise on surgery is a remarkable work, a rational, comprehensive, and well-illustrated text designed to teach the surgeon the details of each treatment, including the types of wound dressings to be used. He recognized the diagnosis of spinal injury, particularly dislo- cation of the vertebrae, and in cases of total subluxation he appreciated that the prognosis was essentially terminal, with the patient showing involuntary activity (passing urine and stool) and flaccid limbs. Regarding the lesser spinal injuries, some of the methods he advocated for reduction of such injuries were rather dangerous in design, depending on a combination of spars and winches. Albucasis held the views of Paul of Aeginata and Avicenna, that bone fragments in the spinal canal should be removed. ${ }^{1,2}$ A review of his writings makes it clear that he was influenced by, and adapted many of the surgical practices of, Paul of Aeginata, and this influence can be seen in the following clinical discussion of a patient with a cervical fracture: ${ }^{51}$

Chapter nine: On setting the vertebrae of the back and neck

When a fracture occurs in the bones of the neck, which is rare, as mostly they suffer contusion, as do the spinal vertebrae-when it happens to anyone and you want to know where it will heal or not, then look and if you see both his hands relaxed and numb and dead and he has no power to move or stretch or close them, and when you pinch them or prick them with a needle he does not notice it or feel any pain in them, you many know, as a general rule, that it will not mend, for he is doomed. But if he moves them both and feels in them the pinching and pricking, you may know that the spinal medulla is still intact and that under treatment the patient will recover.

If anything of this nature happens to the vertebrae of the back and you wish to know if he will recover or not, then pay attention to his feet. If you see them relaxed and in the situation we described in the case of the hands, and when he lies on his back he passes flatus and faeces involuntarily, and lying prone he passes water involuntarily and lying on his back he cannot pass water if he wishes, then you may know this case is hopeless, so do not concern yourself with his treatment. But if nothing of this kind occur then the case is easier.

The way to treat this latter kind of case is to try to reduce the swelling by applying over the injured vertebra oil of roses .

. . If the injury is accompanied by fragmentation or a separation of part of the bone, you must cut down on it and remove the bone; then bring together the edges of the opening, by suture if it be wide; then treat with granulating ointments until it heals.

If the last bone of the coccyx, which is the sacrum of the tail, breaks, introduce the thumb of your left hand into his anus and reset the bone with other hand in whatever way is possible and affords the best setting... if you perceive a fragment in the fracture, cut down upon it, remove it, and dress the wound as before said, until it heals. ${ }^{1}$

\section{Medieval Medicine: Medical Scholasticism}

Beginning approximately in the 11th century, a rise of medicine and medical scholasticism begins in Europe (Fig. 21). At the same time we also begin to see a loss of influence of the Arabic schools of medicine. With this transition to medieval scholasticism, a new concept or school of thought developed in which philosophical and metaphysical explanations and dialectical interpretations became prominent in the medical schools. The most renowned new university or school was the Schola Medica Salernitana, (School of Salerno), based in what is now Naples, Italy, along the southwest coast of the Italian peninsula. ${ }^{15}$ Salerno's medical tradition actually began in the Greco-Roman period, but its dominant period came about during the 11th century. By the middle of the 12th centu- 
ry, not only was the school at its peak as an educational center in medicine, it was now called Hippocratica Civitas (City of Hippocrates). ${ }^{15,44,48-50}$ Interestingly, these educational and medical advances were occurring despite the barbarian invasions of Europe. At Salerno, physicians were being trained and libraries erected and maintained, and through medical scholasticism a medical school flourished. This was also referred to as the golden age of transcription in which many manuscripts were being copied, codified, and passed on. One of the leading groups of scribes in the world was at Salerno, a group that steadfastly produced numerous manuscripts for the School of Salerno and the world.

\section{Constantinus Africanus (1020-1087)}

One cannot discuss the School of Salerno and not recognize one of the most influential individuals to lead this renaissance, who was also a product of medical scholasticism-Constantinus Africanus, magister orientis et occidentis (Master of the East and Master of the West), an important figure in the school of Salerno (Magistri Salerniitani). It was Constantinus who introduced Arabic medicine to Salerno and hence to all of Europe. Constantinus is credited with reviving the Hippocratic and Galenic traditions in European education. Constantinus was born in Carthage, and hence called "the African." He studied at Baghdad, where he came under the influence of Arabic teachings, but interestingly was never formally trained as a physician. In later life he retired to the monastery at Monte Cassino, where he continued to translate Arabic manuscripts into Latin, albeit some say rather inaccurately. Some historians consider him no more than an unscrupulous plagiarist and unreliable translator, but he did bring texts from Arabic to Latin (his writings were the earliest transfer of Arabic medical literature to the West). Thus began a new translation of medical texts back again into Latin (continuing the legacy of Galen), with the Hippocratic writings remaining the inexhaustible source of medical and surgical information. ${ }^{13}$

Constantinus' example allows one to gauge how much medical and surgical knowledge was lost or distorted by inaccuracies in the course of successive translations, particularly of anatomical works. It is notable that Constantinus reintroduced anatomical dissection by performing an annual dissection of a pig, but unfortunately, the anatomical observations that were made as the dissection progressed were compared with those recorded in classical Greek and Latin works. Regrettably, the contemporary anatomical findings that did not match the ancient texts were simply ignored. Constantinus is representative of a period of extensive compilation in which original thought or advance in knowledge was notable chiefly by its absence. From this period, however, came the Regimen Sanitatis Salernitum, the Salernitan directions for health, a work that first appeared in the 12th century and was later republished in approximately 140 different editions. ${ }^{49}$ Despite a strong educational system and a devotion to health care, this remained a period in which surgical education and practice continued to slumber.

The exception to this period of surgical slumber was most likely at Salerno, and the reasons for this likely reflect the constant influx of Crusaders who were using this

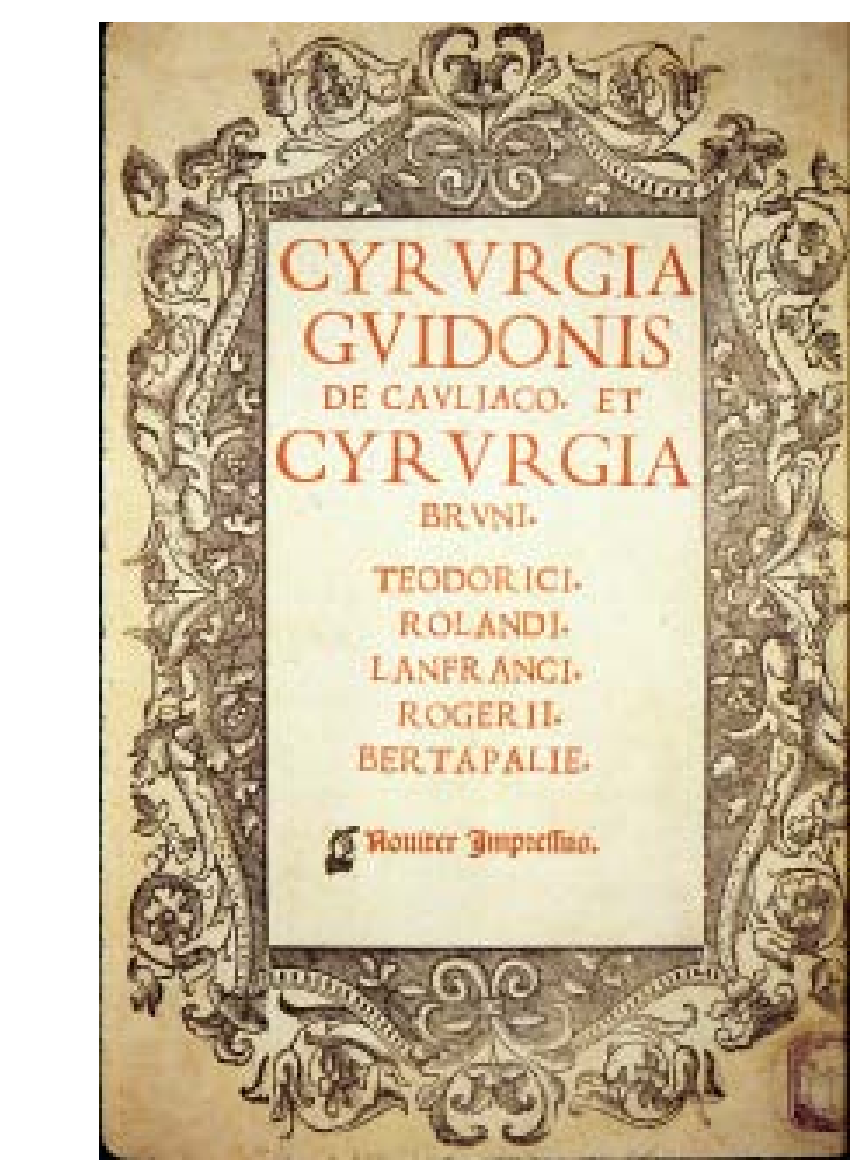

FIG. 25. Title page from a printed work on several early and prominent medieval physicians and surgeons, including the works of the great French surgeon Guy de Chauliac. From Guy de Chauliac: Cyrurgia ... Et Cyrurgia Bruni. Teodorici. Rolandi. Lanfranci. Rogerii. Bertapalie. Noviter impressus.Venetiis: Per Bernardinum Venetum de Vitalibus, 1519.

region as a point of embarkation for the Holy Land. With their constant military games, jousts, and tournaments, it was not uncommon to see injuries of the head and spine in these Crusaders. Unfortunately, the surgeons of this era continued to belong to the less educated class, mostly selftaught practitioners, mountebanks, charlatans, and itinerant road show exhibiters. Contemporary surgical practice of this time consisted primarily of techniques of cautery, cutting, cupping, and purging, with outcomes rarely good. Nevertheless, under the influence of Constantinus and the School of Salerno, many of the surgical and medical texts from the Greco-Roman era were translated and transcribed into Latin. Unfortunately, the surgeon of this period normally could not read and remained mostly poorly educated, so this information was not passed on. Furthermore, a review of the surgical texts produced during this period reveals only a reiteration of the writings of Hippocrates, Galen, Paul of Aeginata, and other early classical physicians. The classical writings and texts were again available in Europe, now in the Latin language, but unfortunately little innovation or new surgical instrument design was provided.

A recent review of some early human skeletons, and in 


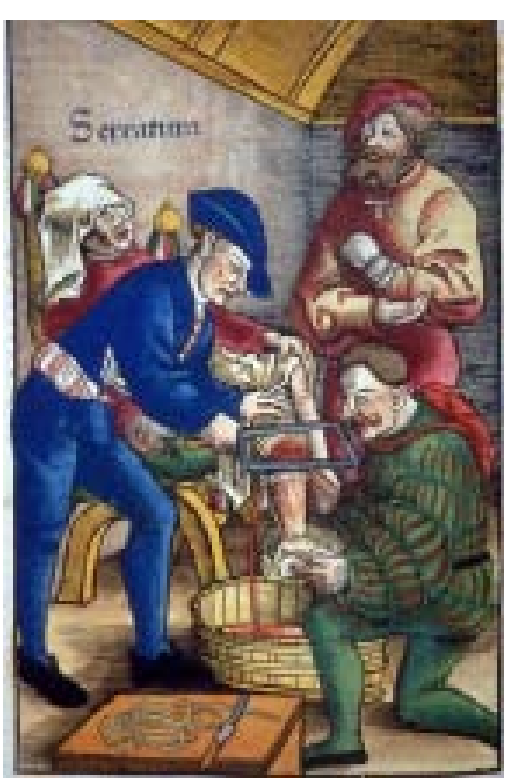

FIG. 26. An early 16th-century illustration demonstrating a surgeon performing an amputation at the beginning of the Renaissance. The image clearly illustrates a lack of many modern surgical adjutants, including anesthesia and antisepsis (although a tourniquet is provided to assist with hemostasis). The cloth over the forehead of the patient is most likely a "soporific sponge" of some type. Courtesy of the Lister Hill Library, University of Alabama Health Sciences Center, Birmingham, Alabama. From von Gersdorff H: Feldbuch der wundartzney. Strassburg: J. Scheur, 1517.

particular cervical spines, has revealed that both degenerative and traumatic injuries to the cervical spine were common during this time. After examining approximately 196 cervical spines from southern Germany from the 6th through 8th centuries, Weber and his colleagues ${ }^{57}$ found extensive evidence of traumatic injuries, including one of the earliest reported cases of an odontoid fracture with pseudoarthrosis. Also documented by this same group of investigators was evidence of tuberculous infection of the spine along with severe kyphosis. ${ }^{58}$ If and how these injuries were treated is not clear, as there was no documented evidence of any surgical intervention.

Several interesting surgical personalities were prominent during this period, individuals who completed a formal education and hence separated themselves from the lowly itinerant barber-surgeon. A review of their contributions reveals some of the common surgical practices of this era. Nancy Sirasi ${ }^{51}$ puts this concept in a clear light in the following quotation:

The existence of a body of specialized knowledge preserved in learned sources soon helped to bring about the emergence of literate surgery as a distinct discipline. Once this material was available, Latin literacy became an important asset for working surgeons. It provided the key to authoritative technical literature, command of which was taken as a mark of competence and intellectual status and hence was closely connected with enhanced social position and economic opportunity. (p. 162)

Roger of Salerno (Rogerius Frugardi of Salerno) (circa 1170)

Roger of Salerno was a surgical leader in the Salerno tradition, considered by many to be the first significant writer on surgery in Italy. ${ }^{44}$ Although many medical works were then available, the appearance of his work Practica chirurgiae $^{45}$ proved to have a tremendous influence on the medieval period, offering several interesting surgical techniques. The first section of the Practica deals with head and spine injuries as commonly seen in military battles, local tournaments, and jousts. Neurosurgeons credit Roger with introducing a unique technique of checking for a tear in the dura mater. To expose or find a leakage of CSF in a patient with a skull fracture, Roger would have the patient hold his breath (a type of Valsalva maneuver), and then carefully watch for a CSF leak or air bubbles. Roger of Salerno was also a pioneer in the techniques of managing nerve injury: he argued for reanastomosis of severed nerves, and paid particular attention to nerve end alignment (Figs. 22-24). ${ }^{45}$

In a 12th-century manuscript attributed to Roger of Salerno (only recently translated from the original and formerly owned by Harvey Cushing), one finds an interesting review of Salernitan surgery, the so-called "Bamberg surgery." ${ }^{14}$ An important description in this work was that of an early anesthetic offered to patients. The Bamberg surgery also contains one of the earliest descriptions of a soporific mixture for relief of surgical pain. The remedy consisted of the bark of a mandragora, opium, hyoscyamus, and levisticum seed, which were mixed together and ground, and then applied wet to the forehead and nostrils of the patient. ${ }^{14}$ In pharmaceutical texts this remedy became known as "spongia soporifera" (a sleep-inducing sponge). ${ }^{15}$ In the field of anatomy Roger of Salerno offered little that was new, contenting himself with recapitulating earlier anatomical treatises, in particular those of Albucasis and Paul of Aeginata. In the surgical treatment of spinal disorders and fractures, Roger followed the guidelines of the early classicists by favoring stabilization in cases of spinal subluxation. Another of his contributions is a discussion in the first chapter on trephination on the treatment of patients with epilepsy. ${ }^{45}$ An important early manuscript in the British Library (Sloane Manuscript No. 1977) contains illustrated examples of various treatments of patients with spinal injuries.

In summary, this was a period in European history characterized by the devastation of war and the Holy Land Crusades, as well as famine, pestilence, and general malaise. Medical knowledge was carefully guarded by monastic recluses in inaccessible mountain retreats, and yet despite this state of affairs a few good surgeons evidently succeeded in mastering their art despite residing in the midst of an era of intellectual darkness.

\section{Theodoric of Cervia (Borgognoni) (1205-1298)}

Theodoric of Cervia was one of the shining stars of medieval surgery, clearly leading the trend away from the itinerant barber-surgeon to one skilled with a university education..$^{52} \mathrm{He}$ was an unusually inventive surgeon, and among his most significant contributions was the use of aseptic technique - not what we would refer to as the "clean" aseptic technique of today, but rather a method based on avoidance of "laudable pus." Among poorly educated surgeons the appearance of pus in a wound was considered desirable and necessary for healing. For reasons 
that are unclear, Theodoric took a different approach and attempted to discover ideal conditions for good wound healing. He concluded that ideal conditions comprised control of bleeding, removal of contaminated or necrotic material, avoidance of dead space, and careful application of a wound dressing bathed in wine. Modern readers might quickly agree that these concepts make for better wound healing and care, but another 700 years would pass along with the work of Lord Lister and others to finally convince surgeons of the validity of these therapeutic goals.

Theodoric's surgical work, written in 1267, provides one of the best overviews of contemporary medieval surgery. ${ }^{45,52}$ Theodoric vigorously argued for meticulous (almost Halstedian) surgical techniques. In his view, the aspiring surgeon needed to train under competent masters and to be well read, that is, well educated in the field of surgery. Arguing for similar views of Roger of Salerno, Theodoric was also interested in the patient's comfort during surgery. To assist the patient's comfort, he developed his own "soporific sponge," which contained opium, mandragora, hemlock, and other less important ingredients. This sponge was applied to the nostrils until the patient fell asleep, and then surgery would proceed. Clearly, the comfort of the patient was considered with the use of this sponge.

By the middle of the 13th century, there was an important change in the types of wounds that were managed by surgeons. The primary antecedent to these types of wounds was the introduction of gunpowder by the Franciscan friar Roger Bacon. The effect of an explosive material on wounds, along with burns and further necrosis, made wound care even more complex for the surgeon. By the second half of the 14th century large weapons were being produced-large bore cannons were being manufactured in Ghent. Handguns first began to appear in the middle of the 15 th century, and were initially massive and clumsy to use; many examples are still on display in European museums. In 1515, a Nuremberg inventor created a wheel lock mechanism, which led to the development of the musket, a weapon that proved to be even more devastating in battle than earlier weapons, and produced much material for the surgeon.

\section{William (Guglielmo) of Saliceto (1210-1277)}

A surgical prodigy who has often been considered the ablest Italian surgeon of the 13th century, William of Saliceto held the rank of professor at the University of Bologna, a unique position for a surgeon. With William's appearance, the focus of Italian education was moving away from the School of Salerno in the south into the more northern Italian universities. William of Saliceto is remembered for his classic work on surgery, Chirurgia. ${ }^{59}$ This work was important not only for its highly original insights into surgical techniques, but also, and more importantly, because it was not in the tradition of the "copyists," that is, it was not based solely on previous writings.

An important innovation by William, which was unique for this period, was the introduction of a separate chapter (Book IV) that dealt solely with anatomy for the surgeon. ${ }^{59}$ He clearly points out that the surgeon must be knowledgeable of anatomy. A clever example that he cites is that of the surgeon working on a neck wound; this individual must be aware of any potential injury to the underlying

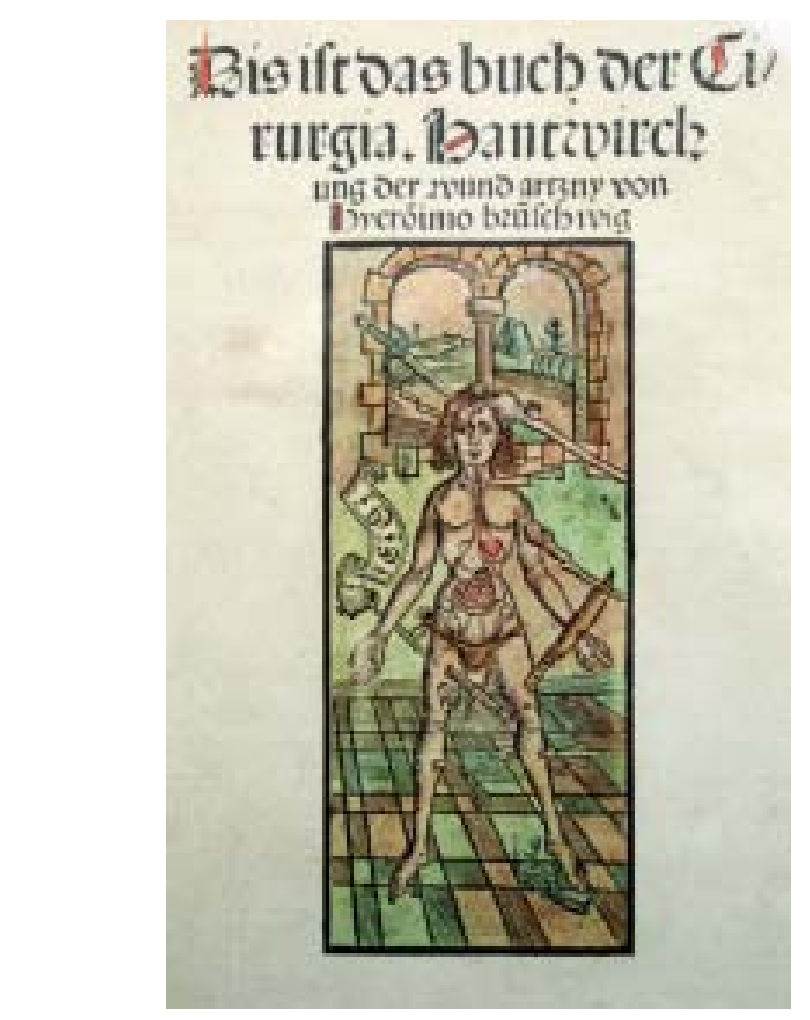

FIG. 27. Rare color title page from the 1497 edition of Buch der Cirurgia, written by Hieronymus Brunschwig, the first surgical work to be written in the vernacular (German). The image depicts a typical "wound man" demonstrating the different types of injuries that a surgeon might have to manage in this period, including head and spinal injury. Reprinted from Brunschwig H: Dis ist das Buch der Cirurgia. Strasburg: J. Grüningeri, 1497.

cervical spinal cord, as failure to do so could result in paralysis..$^{50}$ In William's writing his sources are rarely quoted, although the work is permeated with the influence of Galen, Paul of Aeginata, and Avicenna. William is also remembered for an important surgical innovation: he discarded the early Arabic technique of making an incision by burning with cautery, and instead he used a surgical knife. The modern reader can only imagine the reduction in pain and better surgical outcomes that resulted in reintroducing the surgical knife or scalpel. Among William's other great contributions was devising a series of techniques for primary nerve anastomosis using suturing.

In William's writings on factures and disorders of the spine, he essentially reiterates the earlier views that these lesions are rarely treatable, reflecting a very conservative attitude towards surgery of the spine. This surgical attitude is reflected in a case that he cites of a man who received an arrow injury to the neck leading to partial paralysis. William's initial prognosis was that the man was going to die, and as a result he offered conservative treatment, electing not to attempt to remove the arrow. The man survived with a partial paralysis, and lived for another 10 years, although he had to ambulate with crutches ( $\mathrm{p}$. 173). ${ }^{59}$ In William's view, surgical exploration of the spine was almost never indicated: stabilization with splints, an ancient technique, was recommended instead. 


\section{Leonard of Bertapalia (1380?-1460)}

Leonard of Bertapalia was a prominent figure in 15th century surgery, consistent with a number of skilled and educated surgeons found in Italy. Originating in a small town near Padua, he established an extensive and lucrative practice in that area and in neighboring Venice. Departing from the practice of the barber-surgeon illiterates, Leonard was among the earliest proponents of the study of anatomy. Leonard was an early innovator and in 1429 gave a series of lectures on surgery that included a dissection of an executed criminal. Leonard's writings reveal a strong interest in head injuries, and he devoted over one third of his book to surgery of the brain and spinal column. ${ }^{35,36} \mathrm{He}$ considered the brain the most precious of organs, regarding it as the source of voluntary and involuntary functions. His insights into spine and skull fractures were remarkable for that era. Leonard proposed that physicians always avoid materials that might cause pus in a surgical wound; never use a compressive dressing that could potentially drive bone or debris into the brain or spinal cord; and if a piece of bone is seen piercing the spinal cord during surgery, to gently remove it - a bold and adventurous surgical maneuver for this period. It is interesting to note how his philosophies so closely resembled those of a much earlier surgeon, Paul of Aeginata.

For the modern surgeon it is interesting to recognize a set of rules that Leonard assembled to influence and guide the practice of a 15th century surgeon, that still remain applicable five and a half centuries later:

To ... be the perfect surgeon, you must always bear in mind these eight notations, and remembering them you will be preferred to others. The first task... to become a good surgeon should be to use his eyes... Second, you must accompany and observe the qualified physician, seeing him work before you yourself practice... Third, you must command the most gentle touch in operating and treating lest you cause pain to the patient... Fourth, you must insure that your instruments be sharp and unrusted whenever you cut anywhere ... Fifth, you must be courageous in operating and cutting but timid to cut in the vicinity of nerves, sinews and arteries, and, so as not to commit error, you should study anatomy, which is the mother of this art ... perform your surgery cleverly and never operate on human flesh as if you were working on wood or leather ... Sixth, you must be kind and sympathetic to the poor, for piety and humility greatly augment your reputation and the sick will more freely commit themselves to your care. Seventh, you must never refuse anything brought you as a fee, for the sick will respect you more.

Eighth, you must never argue about fees with the sick, or indeed demand anything unless it be previously agreed upon, for avarice is the most ignoble of vices and should you be so inflicted, you will never achieve the reputation of a good doctor. ${ }^{36}$

\section{Lanfranchi of Milan (died 1306)}

Lanfranchi of Milan, a pupil of William of Saliceto and often referred to as the father of French surgery, was a capable surgeon who fortunately carried forward his teacher's use of the knife in place of the cautery. Though Italian by birth, he was driven from Italy to France early on because of political strife. After seeking refuge in France, he produced his Cyrurgia parva, a work in which he perfected the use of the suture for repairs. ${ }^{34}$ Lanfranchi is remem- bered as an innovative surgeon who developed a unique method of esophageal intubation for surgery, a technique not commonly practiced until the later part of the 19th century. In some of the copies of an early manuscript of his surgical manual, one finds illustrations of surgical instruments of his design along with instruments designed for skull trephination.

Lanfranchi recommended the recently developed and more educationally advanced plan that surgeons should be educated in universities. Lanfranchi elevated the art and science of surgery above the mediocre level of the menial barber-surgeon. Unfortunately, Lanfranchi reintroduced teaching the Arabic use of the hot cautery in place of the scalpel for a surgical incision. In a traditional medieval fashion his treatment of spine lesions and trauma mirrored earlier views, in which only stabilization was recommended. There are no discussions of actual surgery on the spine, and therefore it is not clear whether he would have advocated this form of treatment. In his writings he reveals that a bad prognosis is clearly evident in a patient unable to move his legs, incontinent of urine, or unable to control his bowels.

\section{Henri de Mondeville (died 1317)}

Of the many people who distinguished themselves in medieval surgery, Henri de Mondeville remains one of the most important figures. He was educated at Montpelier and later became a lecturer on surgery there. Henri offered some innovative wound treatments and argued for wound cleanliness so as to obtain the "laudable pus" (a clear white "good" pus rather than the "bad" pus which was thin, watery, and fetid). ${ }^{29,51}$ When presented with this surgical practice of clean wounds, however, his contemporary surgical colleagues responded with contempt and continued to accept the views that laudable pus was better. Henri's surgical teachings advocated wound healing by primary intention, rather than by secondary intention - an original concept for this period (modus novus noster). In the surgical treatment of wounds he urged the surgeon to remove any foreign bodies and also advocated the use of wine dressings in postoperative wound care. It is most unlikely that he knew of the properties of antisepsis, yet the wine did act as an antiseptic and provided better wound healing than the available alternatives.

Henri had begun writing his treatise on surgery in 1306 , but was unable to finish it because of poor health (tuberculosis). Henri was also a designer of surgical instruments and, in particular, is remembered for the design of a special needle holder and also a particularly well-designed instrument for extraction of arrowheads. Of great importance in Henri's surgical writings was the use of illustrations in his Chirurgie, especially anatomical depictions. His work is considered the first to actually make use of illustrations for teaching purposes, a concept virtually unheard of in the 14th century, but widely accepted since the Renaissance.

\section{Guy de Chauliac (1300-1368)}

"In Godes Name. Here bygynnep pe Inuentarie or Gadryng Togedre of Medecyne in the Partye of Gyrurgie, compilede and fulfilled in the yere of oure Loord 1363 by 
Qurparifinfos 3i pormiban the manffolertwe foime ter the for ins finna. Sher sucfroes pianf an

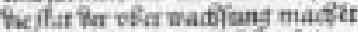

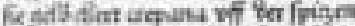

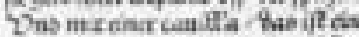

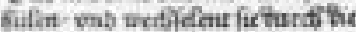
Edfor vons mattent fic Boquarme

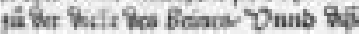
it fin fosm.

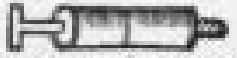

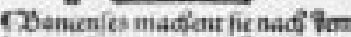
fin cher Langent wan Has f pingege eate miad is tan: wanb afsec fin

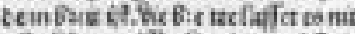
wiertiams uniton tarin gen. Das it the finfatm.

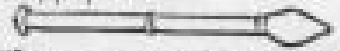

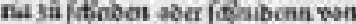

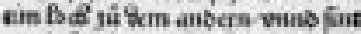

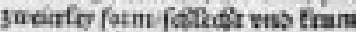
vanb var finem fife mag wetovis en deratracium allo

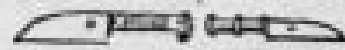

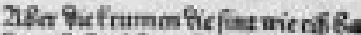

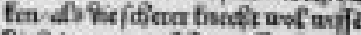

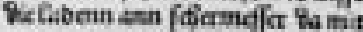
vit an arsier sü folfan wisb fes fo:mift alle

$$
\sqrt{2-20}
$$

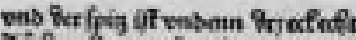

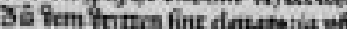

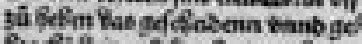
Btode? Bain wif fur fralt gefrum
Yh scm anbens mat fint fenurats ptridiu vinb at os fin foum.

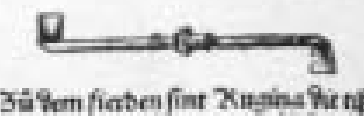

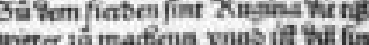
fermi.

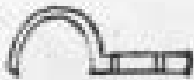

3atem funfften fint fmriaflaria xnb Fas in/trumast of valt get? Ercvos Gualan waris es mades

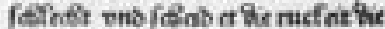
jü f

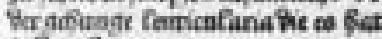
in

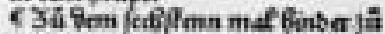
festafin fenticufare ies foefin w5

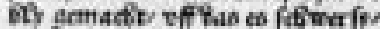

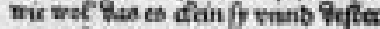
mind fart Vifition fin form

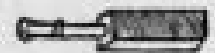

Zlon ftraffung oerzu

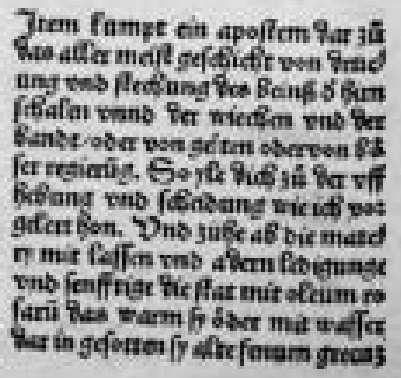

FIG. 28. A page from the 1497 text of Buch der Cirurgia, by Hieronymus Brunschwig, showing some of the instruments (a series of different probes, scalpels, and irrigators) available for surgery on the spine. Most of the instruments shown here were designed and manufactured by Brunschwig. Reprinted from Brunschwig H: Dis ist das Buch der Cirurgia. Strasburg: J. Grüningeri, 1497.

Guydo de Cauliaco, Cirurgene and Doctour of Phisik in the full clere studye of Mountpylerz." (Introduction to a 1363 manuscript by Guy de Chauliac, p. 1) $)^{27}$

From the ever more influential French schools of medicine, in this case the University of Montpelier, came one of the most dynamic surgeons of the fourteenth and fifteenth centuries - Guy de Chauliac. A writer who demonstrated rare learning and a fine historical sense, Guy had an influence so great and widespread that he was asked to be the personal physician to three popes at Avignon (Clement VI, Innocent VI, and Urban V). His surgical writings were both clear and easy to follow and became extremely popular throughout Europe. So popular were his writings, in fact, that they were being copied and translated well into the 17th century. Most modern writers would consider a second edition a major accomplishment: having one's writings reprinted for over four centuries attests to the influence of this great surgeon. His principal didactic surgical text (Collectorium cyrurgie, AD 1363) has remained in print because of popular demand, and a translation into English was published as recently as $1971 . .^{26-28}$ Guy stated four conditions that must be satisfied for a practitioner to be a good surgeon: 1) the surgeon should be learned; 2) he should be expert; 3 ) he must be ingenious; and 4) he should be able to adapt himself (from the introduction of Ars Chirurgica. ${ }^{27} \mathrm{He}$ advocated wound repair by primary suture closure and claimed good results. Guy used egg albumin to stop bleeding and to provide adequate hemostasis, which is always a difficult problem for surgeons. Yet no surgeon practices without some error-for reasons that are not clear, Guy de Chauliac reintroduced the concept of laudable pus in wound healing, which set back surgery approximately 600 years. As noted previously, it was not until the efforts of Lord Lister and Oliver Wendell Holmes and their concepts of asepsis/antisepsis in the latter half of the 19th century that Guy's concepts were reversed (Fig. 25).

Guy de Chauliac's chief work on surgery was divided into three parts, the second part of which deals with a number of subjects, most particularly with wounds, fractures, and dislocations. A combination of accurate anatomical explanations, careful surgical diagnoses, and superb medical ethics pushed this surgeon to the forefront. Guy advocated patient comfort, and to achieve it he also used a narcotic sponge for anesthesia. He was not fearful about cutting out superficial tumors, but was cautious in cutting for the (bladder) stone. He treated fractures and dislocations with splinting and suspension, often using a weight-and-pulley (spars and wenches) system similar to that advocated by Avicenna. In operations on the skull, he advocated cutting the hair prior to surgery; the shaving of the head was performed to reduce infection, a surgical view that still remains a matter of contention among surgeons today. The writings of Guy de Chauliac remained influential in Europe until the publications of Ambrose Paré in the 16th century. The first printed edition of Guy's work appeared in 1478, followed by some 70 editions over the next several centuries, proving to be a most influential work for surgeons. To provide some insights into his thinking, some of his writings on the treatment of wounds are summarized (Fig. 26):

1) To remove foreign bodies, if there be any between the divided parts.

2) To bring together the divided parts.

3) To unite the parts drawn together.

4) To conserve and preserve the tissues.

5) To correct accidents ${ }^{44}$

\section{Hieronymus Brunschwig (circa 1450-circa 1572)}

In the period just before the start of the Renaissance, a publication became available that was to be the first surgical text printed and written in the vernacular (in this case, German rather than Latin). ${ }^{9}$ This important work, titled Buch der Cirurgia, was written by Hieronymus Brunschwig and printed in Strasbourg in 1497, and its importance to contemporary surgeons cannot be overestimated. This was the first printed work to provide illustrations of surgical practice for the surgeon. Although surgeons were becoming more educated, they were not always skilled in Latin, the common medical language of this era. Brunschwig's surgical work, written in the German vernacular, allowed the surgeon not versed in Latin an opportunity to 
review contemporary surgical practice and related ideas. Brunschwig combined the views of ancient and medieval authorities with those he gained from his own clinical surgical practice. One of the earliest discussions of the treatment of gunshot wounds is an important feature in this work; in addition, the book contains several early illustrations showing the surgeon at work as well as illustrated plates of numerous surgical instruments. The text reveals that Hieronymus Brunschwig was a skilled surgeon who operated quickly and understood the importance of hemostasis and avoiding excessive blood loss, especially during amputations. The use of ligatures, tourniquets, and arterial compression was clearly understood by this surgeon. This surgeon and his book clearly increased the standing of a medieval surgeon from a mountebank and itinerant individual to one of a higher class and greater surgical skills, and hopefully better surgical outcomes. In this current age of evidence-based medicine, we can clearly recognize some of the early forerunners of this method in the medieval period (Figs. 27 and 28).

\section{Conclusions}

The Egyptians were responsible for an early understanding of the devastating outcomes of cervical spine injury. The Greco-Roman writers on surgery demonstrated the earliest codification of medicine and surgery. Although the Arabic and medieval periods were eras of great intellectual activity, they were also periods of varied and often not spontaneous intellectual offerings; some writers have argued that this was a period of somnolence as far as originality of thought is concerned. In reviewing the writings of our early fellow surgeons, we clearly see that faith in the teachings of antiquity was excessive. From the fall of the Roman Empire until the beginning of the 16th century, anatomy and the practice of surgery, with only rare exceptions, lay dormant, chained to a staunch Galenic orthodoxy. The translation of medical and surgical writings from Latin, Greek, and Hebrew into Arabic and other Islamic languages, and then back into Latin and local vernaculars, resulted in many errors of interpretation. With very few exceptions, a lack of anatomical knowledge and the inevitable poor surgical outcomes naturally led physicians to recommend against operating on the cervical spine and the spinal cord.

Yet the work presented here shows that despite signs of intellectual paralysis, there still existed prominent personalities who did make advances in surgery, and in particular in cervical spine surgery. These surgical advances often went in opposite directions, with the teachings of laudable pus a clear example of our fellow surgeons' capability of making mistakes. Yet in looking back through history, it is interesting to see how incredibly long it took for cervical and spine surgeons to become established as a surgical specialty. It was not until the 19th century, with the introduction of neurological localization, antisepsis, and anesthesia, that the "modern" development of neurosurgery flourished. When discussing and reviewing progress in the history of medicine and surgery, it is helpful to keep the following concept in mind: "The history of medicine consists of a successive series of intellectual movements proceeding from different centers and each engulfing its predecessor." 50

\section{References}

1. Abu al-Qasim Khalaf ibu Abbas al-Zahrawi: Albucasis On Surgery and Instruments. Spink MS and Lewis GL, translators. Berkeley and Los Angeles: University of California Press, 1973, pp 170-72, 812-819

2. Abu al-Qasim Khalaf ibu Abbas al-Zahrawi: Liber theoricae necnon practicae Alsaharavii. Augsburg: Impensis Sigismundi Grimm \& Marci Vuirsung, 1519

3. Acar F, Naderi S, Guvencer M, Türe U, Arda MN: Herophilus of Chalcedon: a pioneer in neuroscience. Neurosurgery 56:861-867, 2005

4. Aciduman A, Belen D, Simsek S: Management of spinal disorders and trauma in Avicenna's Canon of Medicine. Neurosurgery 59:397-403, 2006

5. Anonymous: The Papyrus Ebers. The Greatest Egyptian Medical Document. Ebbell B, translator. Copenhagen: Levin \& Munksgaard, 1937

6. Avicenna: Liber Canonis, De Medicinis Cordialibus, et Cantica. Basel, Switzerland: Per Joannes Heruagios, 1556

7. Awad IA: Galen's anecodote of the fallen sophist: on the certainty of science through anatomy. J Neurosurg 83:929-932, 1995

8. Breasted JH: The Edwin Smith Papyrus: Published in Facsimile and Hieroglyphic Transliteration with Translation and Commentary in Two Volumes. Chicago: University of Chicago Press, 1930

9. Brunschwig H: Dis ist das Buch der Cirurgia. Strasburg: J. Grüningeri, 1497

10. Celsus AC: De medicina. Florence: Nicolaus Laurentii, 1478

11. Celsus AC: Medicinae Libri VIII. Venice: In aedibus Aldi, et Andreae Asulani soceri, 1528

12. Chapman PH: The Alexandrian Library: crucible of a Renaissance. Neurosurgery 49:1-14, 2001

13. Constantinus Africanus: Constantini Africani Post Hippocratem et Galenum, quorum, Graece linguae doctus, sedulus ... Basileae: Apud Henricum Petrum, 1536

14. Corner GW: On early Salernitan surgery and especially the "Bamberg Surgery" with an account of a previously undescribed manuscript of the Bamberg surgery in the possession of Dr. Harvey Cushing. Bull Inst Hist Med 5:1-32, 1937

15. Divitiis E, Cappabianca P, de Divitiis O: The "Schola Medica Salernitana": the forerunner of the modern University Medical Schools. Neurosurgery 55:722-745, 2004

16. Duckworth WLH: Some Notes on Galen's Anatomy. Linacre Lecture 1948. Cambridge: W Heffer \& Sons Ltd, 1948

17. Elsberg CA: Edwin Smith Papyrus and diagnosis and treatment of injuries to skull and spine. Ann Med Hist 3:271-279, 1931

18. Feldman RP, Goodrich JT: The Edwin Smith surgical papyrus. Childs Nerv Sys 15:281-284, 1999

19. Galen: Omnia quae extant opera in Latinum sermonem conversa. Venice: Apud haeredes Lucaeantonii Juntae, 1576-1577

20. Galen: Opera Omnia (editionen curavit CG Kuhn). Lipsiae, Germany: C. Cnoblock, 1821-1823

21. Galen of Pergamon: On Anatomical Procedures (De anatomicis administrationibus). Translation of the Surviving Books with Introduction and Notes by Charles Singer. London: Oxford University Press, 1956

22. Galen of Pergamon: Galen. On Anatomical Procedures. The Later Books. Transl by W. L. H. Duckworth. Lyons MC and Towers B, editors. Cambridge: Cambridge University Press, 1962

23. Galen C: Experimental section and hemisection of the spinal cord (taken from De Locis affectibus). Ann Med Hist 1: 367-371, 1917

24. Goodrich JT: History of spine surgery in the ancient and medieval worlds. Neurosurg Focus 16(1):E2, 2004

25. Goodrich JT: Neurosurgery in the ancient and medieval worlds, in Greenblatt SH, Dagi TF, Epstein MH (eds): A History of Neurosurgery: in its Scientific and Cultural Contexts. Chi- 
cago: American Association of Neurosurgical Surgeons, 1987, pp 37-64

26. Guy de Chauliac: Cyrurgia ... Et Cyrurgia Bruni. Teodorici. Rolandi. Lanfranci. Gogerii. Bertapalie. Noviter impressus. Venice: Per Bernardinum Venetum de Vitalibus, 1519

27. Guy de Chauliac: The Cyrurgie of Guy de Chauliac. Published by the Early English Text Society. Ogden MS, editor. Oxford: Oxford University Press, 1971

28. Guy de Chauliac: Guy de Chauliac (A.D. 1363): On Wounds and Fractures. WA Brennan, translator. Chicago: WA Brennan, 1923

29. Henri de Mondeville: Chirurgie . . . Composée de la 1306 à 1320. Paris: Félix Alcan, 1893

30. Herophilus: The Art of Medicine in Early Alexandria. von Staden H, translator. Cambridge: Cambridge University Press, 1989

31. Hippocrates: Aphorismi, cum Galeni commentariis, Nicolao Leoniceno interprete, Praedictiones, cum Galeni commentariis, Laurentio Laurentiano interprete. Paris: Simonem Colinaeum, 1527

32. Hippocrates: The Geniune Works of Hippocrates (translated by $F$ Adams). Adams F, translator. London: Sydenham Society, 1844 pp 117-118

33. Hippocrates: Magni Hippocratis Medicorvm Omnivm Facile Principis, Opera Omnia quae extant ... nunc denuo Latina Interpretations \& Annotationbus illustrata Anutio Foesio ... Geneva: S. Chouet, 1657-1662

34. Lanfranchi of Milan: In Guy De Chauliac: Cyrurgia ... Et Cyrurgia Bruni. Teodorici. Rolandi. Lanfranci. Gogerii. Bertapalie. Noviter impressus. Venice: Per Bernardinum Venetum de Vitalibus, 1519

35. Leonard of Bertapalia: In Guy De Chauliac: Cyrurgia ... Et Cyrurgia Bruni. Teodorici. Rolandi. Lanfranci. Gogerii. Bertapalie. Noviter impressus. Venice: Per Bernardinum Venetum de Vitalibus, 1519

36. Leonard of Bertapalia: On Nerve Injuries and Skull Fractures. Ladenheim JC, translator. Mount Kisco, NY: Futura Publishing, 1989

37. Marx KFH: Herophilus: ein Beitrag sur Geschichte der Medicin. Carlsruhe und Baden: Marr, 1838

38. Murray AT: The Iliad/Homer Books 13-24 (translation), ed 2. Cambridge: Harvard University Press, 1999

39. Murray AT, Dimock GE (trans): The Odyssey/Homer Books 1-12 (translation), ed 2. Cambridge: Cambridge University Press, 1999

40. Naderi S, Acar F, Mertol T, Arda MN: Functional anatomy of the spine by Avicenna in his eleventh century treatise Al-Qanun fi al-Tibb (The Canons of Medicine). Neurosurgery 52:1449-1454, 2003

41. Paulus of Aegineta: Opus de re medica nunc primum integrum. Cologne: Opera et impensa Joannis Soteris, 1534

42. Paulus of Aegineta: Seven Books of Paulus Aegineta. Adams F, trans. London: Sydenham Society, 1844-1847

43. Rhazes ABM: Opera parva. Lyons: Impressa per Gilbertum de Villiers, impensis Johannis de Ferris, 1511
44. Riesman D: The Story of Medicine in the Middle Ages. New York: Paul Hoeber, 1936

45. Roger of Salerno: In Guy De Chauliac: Cyrurgia . . . Et Cyrurgia Bruni. Teodorici. Rolandi. Lanfranci. Rogerii. Bertapalie. Noviter impressus. Venice: Per Bernardinum Venetum de Vitalibus, 1519

46. Sahlas DJ: Functional neuroanatomy in the pre-Hippocratic era: observations from the Iliad of Homer. Neurosurgery 48: 1352-1357, 2001

47. Sanan A, Rengachary SS: The history of spinal mechanics. Neurosurgery 39:657-669, 1996

48. Scarborough J: Celsus on human vivisection at Ptolemaic Alexandria. Clio Medica 11:25-38, 1976

49. School of Salerno: Conservandae Bonae Valetvdinis Praecepta Longe Salvberrima, Regi Angiae quondam \& Doctoribus Scholae Salernitantae versibus ... per Ioannem Cvrionem ... Frankfurt Apud Haredes Christiani, 1573

50. Singer CS: A medical compendium of the first half of the twelfth century. Manuscript 17, St. Johns College, Oxford about A.D. 1110. Bull Soc Med Hist 11:53-96, 1917-1922

51. Sirasi N: Medieval and Early Renaissance Medicine. An Introduction to Knowledge and Practice. Chicago: University of Chicago Press, 1990

52. Theodoric of Cervia: Borgognoni: The Surgery of Theodoric ca. A.D. 1267. Campbell E and Colton J, translators. New York: Appleton-Century-Crofts, 1955

53. Tyson RA (ed): Human Paleopathology and Related Subjects. An International Reference. San Diego: San Diego Museum of Man, 1997

54. Tyson RA, Dyer Alcauskas ES: Catalogue of the Hrdlicka Paleopathology Collection. San Diego: San Diego Museum of Man, 1980

55. Viale GL: Return to Galen. Neurosurgery 53:205-210, 2003

56. Viale GL: The spinal cord and its roots according to Galen. Neurosurgery 54:1490-1496, 2004

57. Weber J, Czarnetzki A, Pusch CM: Paleopathological examination of medieval spines with exceptional thoracic kyphosis most likely secondary to spinal tuberculosis. Historical vignette. J Neurosurg Spine 1:238-242, 2004

58. Weber J, Czarnetzki A, Spring A: Paleopathological features of the cervical spine in the early middle ages: natural history of degenerative diseases. Neurosurgery 53:1418-1424, 2003

59. William of Saliceto: Chirurgia. Venice: F. di Pietro, 1474

Manuscript submitted May 18, 2007.

Accepted June 8, 2007.

Address reprint requests to: James Tait Goodrich, M.D., Ph.D., Leo Davidoff Department of Neurological Surgery, Albert Einstein College of Medicine, Children's Hospital of Montefiore, 111 East 210th Street, Bronx, New York 10467. email: goodrich@ aecom.yu.edu. 